\title{
Ecomorphological patterns of the fish assemblage in a tropical floodplain: effects of trophic, spatial and phylogenetic structures
}

\author{
Edson Fontes Oliveira ${ }^{1,2}$, Erivelto Goulart ${ }^{1}$, Luciani Breda ${ }^{1}$, Carolina Viviana Minte-Vera ${ }^{1}$, \\ Luiz Ricardo de Souza Paiva ${ }^{1}$ and Melina Rizzato Vismara ${ }^{1}$
}

\begin{abstract}
Ecomorphological patterns of the fish assemblage from the upper Paraná River floodplain, Brazil, were described and evaluated according to trophic (guilds), spatial (habitats) and phylogenetic (taxonomic distances) structures. The samples were obtained through the Long Term Research Project (LTER-CNPq/UEM/NUPELIA) in August and October 2001. Thirty-five species were analyzed from thirty-one morphological variables. Strong significant correlations (Mantel test) between morphology and trophic guilds and between morphology and taxonomy were found, while morphology and habitat revealed a weak correlation. However, the partial Mantel test showed that the correlations between morphology and trophic guilds persist even when the effect of taxonomy is discounted. The ecomorphological pattern shown by the Principal Component Analysis separated species according to locomotion structures used in feeding. At one extreme there are the piscivores and insectivores that exploit lentic habitats and have compressed bodies and well developed anal fins, while at the other there are detritivores and invertivores that exploit lotic and semi-lotic habitats and have depressed bodies and well developed pectoral, pelvic and caudal fins. Canonical Discriminant Analysis using ecomorphological variables successfully predicted $94.5 \%$ of the trophic guild ecomorphotypes, but only $57.1 \%$ of the habitat ecomorphotypes. These data indicate that the fish assemblage of the upper Paraná River floodplain is structured ecomorphologically mainly according to trophic structure rather than habitat.
\end{abstract}

Este trabalho objetivou descrever e avaliar os padrões ecomorfológicos da assembleia de peixes da planície de inundação do alto rio Paraná, Brasil, analisando os efeitos das estruturas trófica (guildas), espacial (tipos de habitats) e filogenética (distância taxonômica). Trinta e cinco espécies foram analisadas a partir de 31 variáveis morfológicas obtidas de espécimes coletados em agosto e outubro de 2001 no âmbito do Projeto Ecológico de Longa Duração (PELD-CNPq/UEM/NUPELIA). O teste de Mantel revelou que há correlação significativa das distâncias morfológicas com guildas tróficas e distâncias taxonômicas, enquanto com os tipos de habitats a correlação se mostrou fraca. Contudo, o teste de Mantel parcial demonstrou que a correlação da morfologia com as guildas tróficas independe da filogenia. O padrão de diversificação ecomorfológica apresentado pela Análise de Componentes Principais revelou um gradiente ecomorfológico relacionado à locomoção associada à ecologia trófica. Em um extremo estão espécies de piscívoros e insetívoros que exploram preferencialmente habitats lênticos com corpos comprimidos e nadadeiras anais desenvolvidas, enquanto no outro extremo estão os detritívoros e invertívoros que exploram preferencialmente habitats lóticos e semi-lóticos e apresentam corpos deprimidos e nadadeiras peitorais, pélvicas e caudais desenvolvidas. A Análise Discriminante Canônica realizada com os índices ecomorfológicos previu com sucesso $94,5 \%$ dos ecomorfotipos relacionados às guildas tróficas e apenas $57,1 \%$ dos ecomorfotipos que exploram os diferentes habitats analisados. Conclui-se que a assembleia de peixes da planície de inundação do alto rio Paraná está estruturada ecomorfologicamente, revelando-se mais influenciada pela estrutura trófica do que pela espacial.

Key words: Ecomorphology, Ecomorphotypes, Trophic guilds, Habitat diversity, Phylogeny, Upper Paraná River.

${ }^{1}$ Programa de Pós-Graduação em Ecologia de Ambientes Continentais (PEA), Núcleo de Pesquisas em Limnologia, Ictiologia e Aquicultura (NUPELIA), Universidade Estadual de Maringá (UEM). Av. Colombo, 5790, 87020-900 Maringá, PR, Brazil. edsfontes@gmail.com (EFO), goulart@nupelia.uem.br(EG), lucianibreda@yahoo.com.br(LB), cminte@nupelia.uem.br(CVMV), paivafish@hotmail.com(LRSP), melrizzato@gmail.com (MRV).

${ }^{2}$ Present address: Universidade Tecnológica Federal do Paraná (UTFPR), Campus de Londrina. Av. dos Pioneiros, 3131, 86036-370 Londrina, PR, Brazil. 


\section{Introduction}

The correlations between the morphological variables of fish assemblages and diet or habitat use have been analyzed in several hypotheses tests. The results of these tests do not reveal a general pattern for fish assemblages of tropical and temperate aquatic environments. Some studies have revealed a strong relationship between morphology and diet, such as: very long digestive tracts are commonly positively correlated with detritivory and herbivory; long and thin gill rakers are generally associated with the consumption of plankton; and head and mouth sizes are related to prey size in piscivores (Gatz Jr., 1979; Wikramanayake, 1990; Piet, 1998; Hugueny \& Pouilly, 1999; Delariva \& Agostinho, 2001; Xie et al., 2001; Ward-Campbell et al., 2005; Costa \& Cataudella, 2007; Maldonado et al., 2009; Cochran-Biederman \& Winemiller, 2010). The morphological variables are also related to feeding behavior. Mouth orientation and eyes position are commonly associated with the preferential relative position of the fish as regards its food (Gatz Jr., 1979).

Considering habitat use, some relationships have also been widely established. For example, fishes with depressed bodies exploited the sediment because they reduce hydrostatic pressure that tends to lift them up from the substrate; laterally compressed fishes inhabit structured environments since they have greater maneuverability, whereas the fusiforms are typically pelagic, once they reach high speed (Keast \& Webb, 1966; Gatz Jr., 1979; Chan, 2001; Breda, 2005; Willis et al., 2005; Herler, 2007; CochranBiederman \& Winemiller, 2010). However, others authors have found relatively weak or indistinct relationships among morphology and habitat use (Felley, 1984; Douglas \& Matthews, 1992; Motta et al., 1995; Casatti \& Castro, 2006).

Currently, even with many studies reporting strong correlations between the ecology and the morphology of species, there are no consolidated predictive models for fish assemblages in different types of environments. The causes of this discrepancy may be related to the high degree of opportunism of freshwater fish (Hugueny \& Pouilly, 1999), the influence of phylogeny limiting the detection of morphological adaptation (Douglas \& Matthews, 1992; Motta et al., 1995) and the diversity of statistical methods used by the authors (Ricklefs \& Miles, 1994). In addition, inadequate selection of morphological variables related to diet and habitat use may also be responsible for the failure to detect predictive patterns, whether it is because of a lack of experimental studies of functional morphology that allow the selection of the most important morphological variables in the performance of a determined ecological activity (Alexander, 1988; Bock, 1999) or even due to possibility that the selection of variables has to be differentiated for the different phylogenetic groups.

This study describes the ecomorphological patterns of fish assemblage in the upper Paraná River floodplain (Brazil) and evaluates trophic (guilds), spatial (habitat types) and phylogenetic (taxonomic distance) effects on the morphological dimension. We investigated four specific issues: (i) the correlations between morphological variables of species and trophic guilds and the exploited habitat types, (ii) the correlations between morphology and trophic guilds and habitats without the influence of taxonomic relationships between the species, (iii) the interspecific ecomorphological diversification patterns of assemblage and, (iv) if the ecomorphotypes (ecomorphological groups) formed from trophic guilds and habitat types may be predicted by body shape of species.

The working hypothesis presupposes that the morphology of species is similar within of each trophic guild and the habitat type exploited on the floodplain. Thus, the morphology of the species would differ among trophic guilds, by the nature of the food resource used and by the strategy of the species to exploit it, and would differ among habitats by its physical and limnological characteristics. Therefore, it is assumed that these characteristics define the ecomorphotypes related to the trophic guilds and the habitat types. In this sense, we defined ecomorphotype as a group of individuals that exploit the same environmental resources using a similar set of morphological variables, independent of the phylogenetic relationships among its members. The possible morphological variations found would correspond to responses to selective pressures of the environment on different phylogenetic groups, resulting in convergence, i.e., morphological similarity of phylogenetically unrelated species, or morphological divergence among phylogenetically close species.

\section{Material and Methods}

Study area. Paraná is the second largest river of South America $\left(4,695 \mathrm{~km}\right.$ long, with a drainage area of $3.1 \times 10^{6} \mathrm{~km}^{2}$ and flow peaks of $\left.65 \times 10^{3} \mathrm{~m}^{3} \cdot \mathrm{s}^{-1}\right)$ (Bonetto, 1986). The Brazilian portion of the Paraná River basin covers a vast area of $891,150 \mathrm{~km}^{2}$ (10.5\% of the total area) (Agostinho \& Zalewski, 1996). The studied area consisted of a large floodplain located in the lower third of the upper Paraná River. The braided floodplain is formed by secondary channels, among which are lotic (rivers), semilotic (channels) and lentic (connected and disconnected lagoons) environments belonging to the basins of the Paraná,

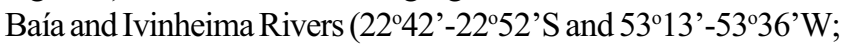
Fig. 1). The physiognomic and limnological characteristics of the different types of habitats are described in Table 1.

Sampling. Fishes were collected in August and October 2001 using sets of gill nets ( 2 to $16 \mathrm{~cm}$ mesh). Fishing gears were set for $24 \mathrm{~h}$ periods, checked at early morning, dusk and late evening. The samplings were carried out by Long-Term Ecological Research (LTER/CNPq/UEM/NUPELIA - site 6) Program developed by the Universidade Estadual de Maringá in the upper Paraná River floodplain. The species were identified according to Graça \& Pavanelli (2007) and the taxonomic framing was carried out based on Reis et al. (2003). A voucher collection was made and is stored at the synoptic collection of the Núcleo de Pesquisas em Limnologia, Ictiologia e Aquicultura of the Universidade Estadual de Maringá. 


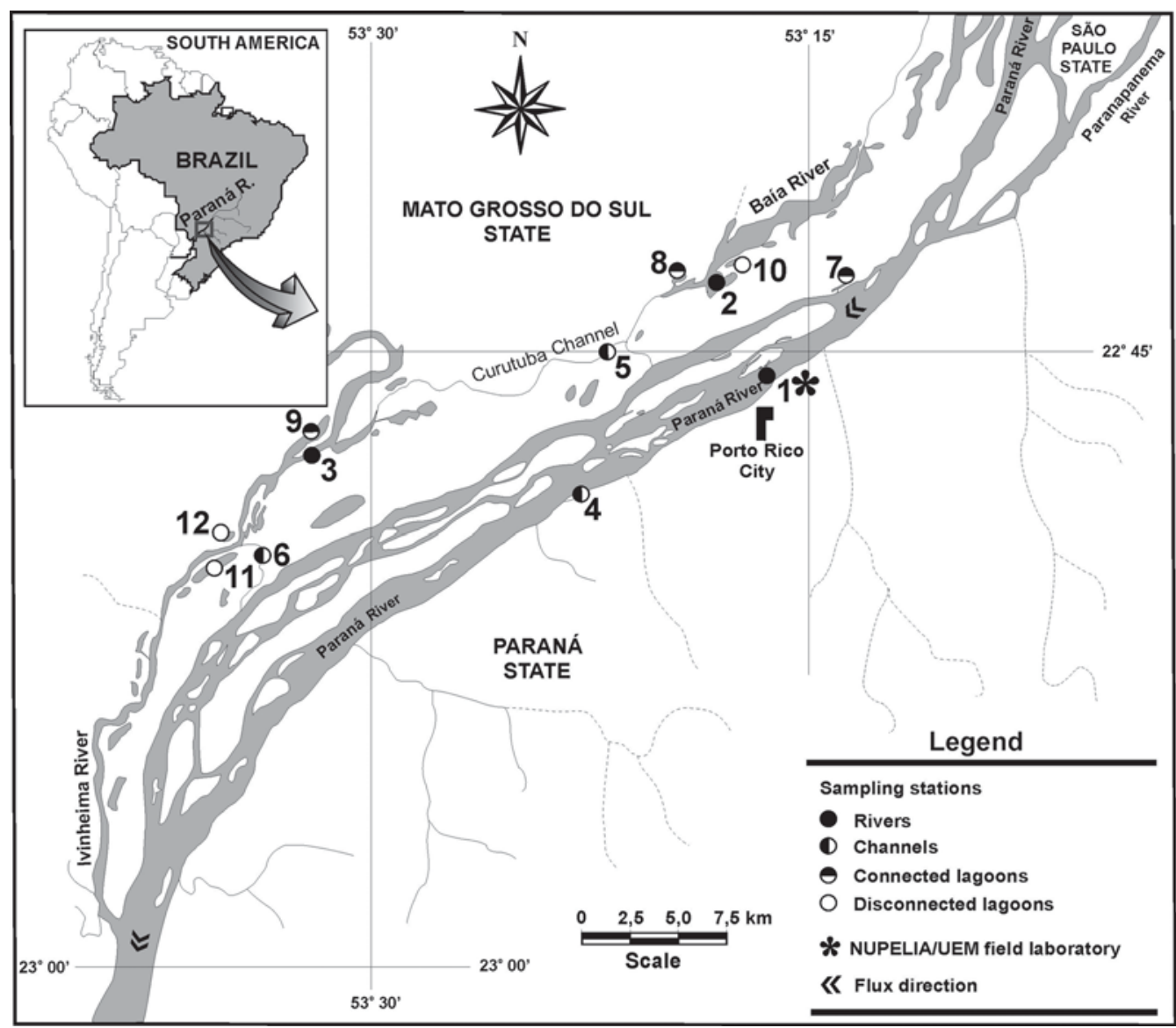

Fig. 1. Study area with sampling stations in the upper Paraná River floodplain: rivers: Paraná (1), Baía (2) and Ivinheima (3); channels: Cortado (4), Curutuba (5) and Ipoitã (6); connected lagoons: Garças (7), Guaraná (8) and Finado Raimundo (9); disconnected lagoons: Fechada (10), Ventura (11) and Zé do Paco (12).

Linear morphometric measurements, areas and ecomorphological indices. The linear morphometric measurements and selected areas are related to trunk, fins, head, eye and mouth based on the literature about functional morphology (Alexander, 1967; Aleev, 1969; Gosline, 1971; Lindsey, 1978; Webb, 1980; Lauder, 1989; Videler, 1993; Helfman et al., 1997; Wilga \& Lauder, 1999; Blake, 2004). Ecomorphological indices were obtained from these measurements and areas, which expressed the shape of the morphological structures and consequently revealed their ecological roles (Hora, 1922; Keast \& Webb, 1966; Gatz Jr., 1979; Watson \& Balon, 1984; Balon et al., 1986; Wikramanayake, 1990; Winemiller, 1991; Barrella et al., 1994; Beaumord \& Petrere Jr., 1994; Freire \& Agostinho, 2001; Wainwright et al., 2002; Pouilly et al., 2003; Breda, 2005; Willis et al., 2005; Casatti \& Castro, 2006). As these indices are ratios, therefore, independent of specimen size, they eliminate this effect and allow interspecific comparisons only related to body shape (Gatz Jr., 1979; Winemiller, 1991).

The measurements were taken from recently caught specimens aiming to avoid morphometric variability induced by preservation substances (Peterson \& VanderKooy, 1996). Only adult individuals (Vazzoler, 1996; Suzuki et al., 2004) were used because ontogenetic development can cause changes in body shape (Pakkasmaa et al., 1998), feeding habit (Piet, 1998; Russo et al., 2007) or habitat use (Sagnes et al., 1997). Species with only one or two individuals were excluded from the analyses because such small samples do not allow detection of specific morphological variations. Linear morphometric measurements were taken in $\mathrm{cm}$ (and an approximation of $\mathrm{mm}$ ) using a manual caliper, except for measurements larger than $15 \mathrm{~cm}$ of length (taken using a metal ruler). The areas of eyes and fins were obtained from drawings of its outlines, which were later scanned and inserted into the AutoCAD software (Autodesk, 2004) to calculate the internal area. All the morphological variables were collected on the left side of the specimens.

Twenty-five linear morphometric measurements were taken and six areas calculated (Fig. 2). Twenty-two ecomorphological indices were calculated from the linear morphometric measurements and the areas: compression index (CI), depression index (DI), relative length of caudal peduncle (RLPd), relative height of caudal peduncle (RHPd), relative width of caudal peduncle (RWPd), relative length of head (RLHd), relative height of head (RHHd), relative width of head (RWHd), relative height of mouth (RHM), relative width of mouth (RWM), protrusion index (PI), eye position (EP), relative area of eye (RAE), relative 
Table 1. Physiognomic and limnological characteristics of the different types of habitats on the upper Paraná River floodplain. The quantitative variables are presented as mean \pm standard deviation.

\begin{tabular}{|c|c|c|c|c|}
\hline & \multicolumn{4}{|c|}{ Habitats } \\
\hline & Rivers & Channels & Connected lagoons & Disconnected lagoons \\
\hline $\begin{array}{l}\text { Plant physiognomy } \\
\text { (during the period } \\
\text { of fish collection) }\end{array}$ & $\begin{array}{l}\text { Littoral areas with less than } \\
25 \% \text { of floating macrophyte } \\
\text { cover, especially Eichhornia } \\
\text { azurea in the Ivinheima } \\
\text { River. The margins presented } \\
\text { diversified plant } \\
\text { physiognomies. }\end{array}$ & $\begin{array}{l}\text { Littoral areas covered more than } \\
25 \% \text { by macrophytes. Due to the } \\
\text { drought period, Cortado } \\
\text { Channel recorded more than } \\
50 \% \text { of its area covered. The } \\
\text { margins presented shrub-tree } \\
\text { vegetation, especially Cecropia } \\
\text { pachystachya. }\end{array}$ & $\begin{array}{l}\text { Presence of small floating } \\
\text { macrophyte banks in } \\
\text { Guaraná and Finado } \\
\text { Raimundo Lagoons. Margins } \\
\text { covered by grasses, with the } \\
\text { surrounding area composed } \\
\text { of several layers of riparian } \\
\text { vegetation. }\end{array}$ & $\begin{array}{l}\text { Littoral areas with more than } 25 \% \text { of } \\
\text { macrophyte cover, especially } \\
\text { Eichhornia crassipes and Salvinia } \\
\text { auriculata in Zé do Paco Lagoon. } \\
\text { Surrounding vegetation composed of } \\
\text { species from Cyperaceae family and } \\
\text { grasses and, less densely, by } \\
\text { emergent Polygonum ferrugineum. }\end{array}$ \\
\hline Littoral depth & $3.3 \pm 0.9 \mathrm{~m}$ & $2.5 \pm 1.0 \mathrm{~m}$ & $2.2 \pm 0.8 \mathrm{~m}$ & $2.9 \pm 0.9 \mathrm{~m}$ \\
\hline $\begin{array}{l}\text { Hydrodynamics } \\
\text { and morphometry }\end{array}$ & $\begin{array}{c}\text { Lotic environments with } \\
\text { varied widths, characterized } \\
\text { by high current mean } \\
\text { velocity (close to } 1 \mathrm{~m} / \mathrm{s} \text { ), } \\
\text { varying according to the } \\
\text { flow. }\end{array}$ & $\begin{array}{l}\text { Semi-lotic environments } \\
\text { characterized by reduced } \\
\text { velocity, with possibility of } \\
\text { change in direction of the water } \\
\text { current. They present dynamics } \\
\text { influenced by alterations in the } \\
\text { hydrometric levels of the } \\
\text { Paraná River. }\end{array}$ & $\begin{array}{l}\text { Lentic environments that } \\
\text { maintain a constant } \\
\text { connection with rivers or } \\
\text { channels. They are slightly } \\
\text { rounded and do not have } \\
\text { defined boundaries because } \\
\text { gradually become } \\
\text { flooded areas. }\end{array}$ & $\begin{array}{l}\text { Elongated lentic environments that } \\
\text { occupy the more depressed areas of } \\
\text { the floodplain, constituting isolated } \\
\text { bodies of water. Sedimentation } \\
\text { intense with a predominance of mud } \\
\text { and organic matter. }\end{array}$ \\
\hline $\begin{array}{l}\text { Limnological } \\
\text { variables }(2000 \\
\text { and } 2001)\end{array}$ & $\begin{array}{l}\text { Higher mean values of water } \\
\text { transparency }(1.2 \pm 0.9 \mathrm{~m}) \\
\text { and dissolved oxygen } \\
\left(7.7 \pm 1.4 \mathrm{mg} . \mathrm{L}^{-1}\right) \text { and, lower } \\
\text { mean values of turbidity } \\
(12.8 \pm 7.8 \mathrm{NTU}) \text { and } \\
\text { suspended material } \\
\left(8.4 \pm 5.5 \mathrm{mg} . \mathrm{L}^{-1}\right) .\end{array}$ & $\begin{array}{l}\text { Higher mean values of electrical } \\
\text { conductivity }\left(53 \pm 13.9 \mu \mathrm{S} . \mathrm{cm}^{-1}\right) \\
\text { and lower mean values of total } \\
\text { nitrogen }\left(340.7 \pm 145.7 \mu \mathrm{g} . \mathrm{L}^{-1}\right) \\
\text { and total phosphorus } \\
\quad\left(21.7 \pm 13.7 \mu \mathrm{g} . \mathrm{L}^{-1}\right) .\end{array}$ & $\begin{array}{l}\text { Higher mean values } \\
\text { of total nitrogen } \\
\left(540.3 \pm 369.4 \mu \mathrm{g} . \mathrm{L}^{-1}\right) \text { and } \\
\text { lower mean values of water } \\
\text { transparency } \\
(0.5 \pm 0.2 \mathrm{~m})\end{array}$ & $\begin{array}{l}\text { Higher mean values of turbidity } \\
(53.4 \pm 45.2 \mathrm{NTU}), \text { suspended } \\
\text { material }\left(13.9 \pm 11.9 \mathrm{mg} . \mathrm{L}^{-1}\right) \text { and } \\
\text { total phosphorus }\left(72.4 \pm 64.1 \mu \mathrm{g} . \mathrm{L}^{-1}\right) \\
\text { and lower mean values of electrical } \\
\text { conductivity }\left(34.2 \pm 9.5 \mu \mathrm{S} . \mathrm{cm}^{-1}\right) \\
\text { and dissolved oxygen } \\
\left(6.2 \pm 1.9 \mathrm{mg} . \mathrm{L}^{-1}\right) .\end{array}$ \\
\hline
\end{tabular}

area of dorsal fin (RAD), relative area of caudal fin (RAC), aspect ratio of caudal fin (ARC), relative area of anal fin (RAA), aspect ratio of anal fin (ARA), relative area of pectoral fin (RAPt), aspect ratio of pectoral fin (ARPt), relative area of pelvic fin (RAPv) and aspect ratio of pelvic fin $(\mathrm{ARPV})$. The variables involved in the calculation of the indices, as well as their respective ecological explanations, are described in Appendix 1.

Data analysis. Ecomorphological structure of the assemblage. The null hypothesis that the morphological patterns of the fish assemblage of the upper Paraná River floodplain are independent of phylogenetic, spatial and trophic structures was tested using the Mantel test. The Mantel test is given by the expression (Legendre \& Legendre, 1998):

$$
Z=\sum_{i=1}^{n} \sum_{j=1}^{n} X_{i j} Y_{i j} \text {, for } i \neq j,
$$

in which, $X_{i j}$ and $Y_{i j}$ are elements of the two matrices ( $X$ and $Y$ ) that are being compared. The statistical significance of the correlation between these two matrices is obtained by $n$ randomizations of the data of one of the matrices, recalculating the value of $Z n$ times. Thus, the reference distribution of randomized $Z$ is obtained and compared to observed $Z$. In this study, the Mantel test was used to test the correlations between the matrix of morphological distances and the model matrices for trophic (guilds), spatial (habitat types) and phylogenetic (taxonomic position) structures.

The morphological distances were calculated based on the mean Euclidian Distances between the ecomorphological indices for each pair of species, according to the following formula (Gotelli \& Ellison, 2004):

$$
\text { Euclidian Distance }\left(\mathrm{D}_{\mathrm{jk}}\right)=\left[\sum_{i=1}^{n}\left(x_{i j}-x_{i k}\right)^{2}\right]^{1 / 2}
$$

in which, $n=$ number of ecomorphological indices and, $x_{i j}$ and $x_{i k}=$ values of the ecomorphological index $i$ for the pair of species $j$ and $k$. The Euclidian Distances were calculated using the indices without standardization to preserve their variation amplitudes, which can indicate the amplitude of the trophic and spatial niches that potentially may be exploited by the species.

The model matrices were obtained attributing a value of one to the pair of species that belonged to the same trophic guild or that had been collected in the same habitat type, and a value of zero to the pair that did not satisfy these conditions. The classification of the trophic guilds (piscivores, insectivores, detritivores, invertivores, herbivores and omnivores) was based on information about diet and feeding behavior of species in the upper Paraná River basin between the Itaipu Reservoir dam and the upstream portion of the floodplain (Hahn et al., 2004; Peretti \& Andrian, 2004). The characterizations of the floodplain habitat types (rivers, channels, connected and disconnected lagoons) were based on physiognomic, geomorphological (Souza Filho \& Stevaux, 2004) and limnological (Thomaz et al., 2004) descriptions of the upper Paraná River floodplain.

The model matrix of taxonomic distance was constructed from standardized counting of the number of knots that separates each species on the taxonomic tree (Pouilly et al., 2003). A value of 1 (one) was attributed to the species that 

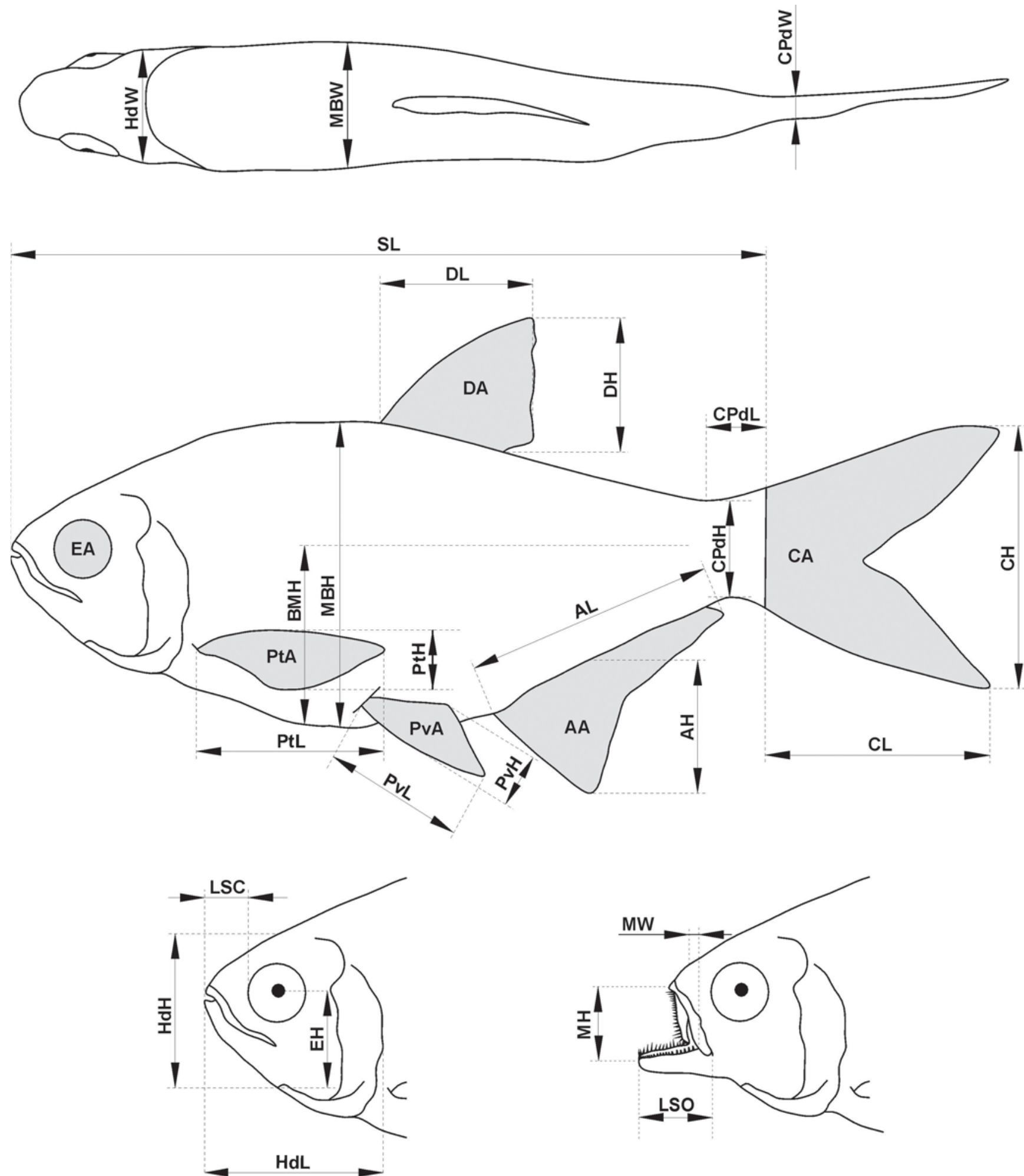

Fig. 2. Schematic representation of the linear morphometric measurements and the calculated areas: standard length (SL), maximum body height $(\mathrm{MBH})$, body midline height $(\mathrm{BMH})$, maximum body width (MBW), caudal peduncle length $(\mathrm{CPdL})$, caudal peduncle height $(\mathrm{CPdH})$, caudal peduncle width $(\mathrm{CPdW})$, head length $(\mathrm{HdL})$, head height $(\mathrm{HdH})$, head width (HdW), length of snout with the mouth closed (LSC), length of snout with the mouth open (LSO), eye height (EH), mouth height $(\mathrm{MH})$, mouth width (MW), dorsal fin length (DL), dorsal fin height (DH), caudal fin length (CL), caudal fin height $(\mathrm{CH})$, anal fin length $(\mathrm{AL})$, anal fin height $(\mathrm{AH})$, pectoral fin length $(\mathrm{PtL})$, pectoral fin height $(\mathrm{PtH})$, pelvic fin length $(\mathrm{PvL})$, pelvic fin height $(\mathrm{PvH})$, eye area $(\mathrm{EA})$, dorsal fin area $(\mathrm{DA})$, caudal fin area $(\mathrm{CA})$, anal fin area $(\mathrm{AA})$, pectoral fin area (PtA), and pelvic fin area (PvA). 
belonged to the same genus, a value of 1.5 (one and a half) to the same subfamily, a value of 2 (two) to the same family, a value of 3 (three) to the same order and a value of 4 (four) to those that did not belong to the same order.

The relationships between morphology and trophic and spatial structures may be an artifact derived from the phylogenetic distance among species (Douglas \& Matthews, 1992; Hugueny \& Pouilly, 1999). A partial Mantel test was carried out to evaluate the effect of phylogeny (Smouse et al., 1986). It assesses the partial correlation between two matrices controlling the effect of a third. Regressions of the morphological distances and the model matrices of trophic guilds and habitat types with the taxonomic distance were performed. Mantel test compared the matrix of residuals of the regression of morphology on the phylogeny with the matrices of residuals of the regression of trophic guilds and habitats, having the phylogeny as independent variable. Thus, the morphology matrices were compared with guild and habitat matrices without the effect of phylogenetic relationships between the species. The Mantel and partial Mantel tests were carried out using the NTSYS-pc software (Rohlf, 1989) and statistical significance was estimated using 20,000 permutations from the model matrices.

Patterns of interspecific ecomorphological diversification. Principal Components Analysis (PCA) was used to evaluate tendencies in the interspecific variations in the fish assemblage in the multivariate ecomorphological space, as well as to identify diversification patterns in the body shape related to the use of environmental resources. The PCA was applied to the correlation matrix (Pearson) formed by 22 ecomorphological indices for 35 species using the PC-ORD v.4.01 software (McCune \& Mefford, 1999). This analysis reduces the dimensionality of data because it identifies variables that summarize maximum variability (Gotelli \& Ellison, 2004).

Unlike the criterion adopted in the Mantel test, in which the variation amplitudes of the original indices were kept to test the hypothesis of ecomorphological structuration in the assemblage, the Pearson correlation index applied in PCA standardizes the data within its amplitude of values (between -1 and +1$)$. This standardization intended to create a simplified ecomorphological space. In this space, the variables that contribute most to the segregation of different body shapes are shown in a way that gives the same importance to the variables with distinct variation amplitudes.

The selection of the axes for interpretation was carried out according to the broken stick model (Jackson, 1993), which creates a null distribution of eigenvalues for comparison with the observed eigenvalues. Only eigenvalues greater than those expected by chance were retained for interpretation, i.e., indicating axes with patterns significantly different from those found by chance.

Prediction of ecomorphotypes. Canonical Discriminant Analysis (CDA) is recommended to determine which variables are most important in the segregation between two or more groups formed a priori (Albrecht, 1980; Johnson, 1998; Gotelli \& Ellison, 2004). In this study, CDA was used to verify which ecomorphological indices were most important in the segregation of the species that constitute the trophic guilds and exploit the habitat types. Therefore, the definition of these ecomorphotypes, a priori, allows to infer which variables can better predict the characteristics of the species that compose them.

Initially, Multivariate Analysis of Variance (MANOVA) was used on the ecomorphological indices to test the null hypothesis that there are no significant differences between the ecomorphotypes observed a priori, i.e., trophic guilds and habitat types. The MANOVA calculated Wilks $\lambda$, which varies between zero (maximum dispersion between the groups) and one (no dispersion between the groups) (Legendre \& Legendre, 1998). With the rejection of the null hypothesis, CDA was used to evaluate the ecomorphological relationships among species in the multivariate space through linear combinations of variables, maximizing the distances between the groups. Both MANOVA and CDA were carried out using the STATISTICA v.6.1 software (StatSoft, 2003).

The variables with high absolute values of correlation with the canonical axes of the CDA contributed more to the discrimination of the body shape of analyzed groups (Albrecht, 1980). The canonical scores of the individuals were projected in the reduced space of the canonical axes and showed the patterns of discrimination among the ecomorphotypes analyzed. Additionally, the CDA model reclassified the elements that compose the observed groups based on the distances between each observation and the centroids of each group (Johnson, 1998). Thus, percentage of correct reclassification reveals the predictive success of the ecomorphotypes based on the morphological variables.

\section{Results}

The fish assemblage sample from the upper Paraná River floodplain analyzed in this study contained 653 individuals distributed among 35 species, 15 families and 3 orders (Characiformes, Perciformes and Siluriformes) (Table 2).

Ecomorphological structure of the assemblage. The results of the Mantel test revealed that there are significant correlations between the matrices of morphological distance (Euclidian Distance between the ecomorphological indices) and the matrices of trophic guilds and taxonomic distance. Therefore, the morphological structure of the assemblage is dependent of the trophic $(p=0.04)$ and phylogenetic $(p=0.01)$ structures (Table 3 ). Habitat type exploited by the species did no present significant effect $(p=0.06)$, showing that the morphological structure is weakly affected by structure spatial of the assemblage in the floodplain.

As Table 3 also shows that body shape was significantly correlated with taxonomic distance, the correlations between trophic-morphological and spatial-morphological structures may be a spurious subproduct of the taxonomic relationships. 
Table 2. Systematic position of species, classification according to trophic guilds in the upper Paraná River floodplain (Hahn et al., 2004; Peretti \& Andrian, 2004), habitats (river, channel, conlag = connected lagoons, disclag = disconnected lagoons), total number ( $\mathrm{N}$ and \%), mean $(\bar{x})$ and standard deviation (sd) of standard length (SL, cm) of individuals analyzed in this study.

\begin{tabular}{|c|c|c|c|c|}
\hline \multirow{2}{*}{ Species } & \multirow{2}{*}{ Habitats } & \multirow{2}{*}{$\begin{array}{l}\text { Trophic } \\
\text { guilds }\end{array}$} & \multirow{2}{*}{$\mathrm{N}(\%)$} & \multirow{2}{*}{$\begin{array}{c}\mathrm{SL}(\mathrm{cm}) \\
\bar{x} \pm \mathrm{sd}\end{array}$} \\
\hline & & & & \\
\hline \multicolumn{5}{|l|}{ Osteichthyes } \\
\hline \multicolumn{5}{|l|}{ Characiformes } \\
\hline \multicolumn{5}{|l|}{ Acestrorhynchidae } \\
\hline Acestrorhynchus lacustris (Lütken, 1875) & Channel and conlag & Piscivore & $7(1.07)$ & $18 \pm 2.87$ \\
\hline \multicolumn{5}{|l|}{ Anostomidae } \\
\hline Leporinus friderici (Bloch, 1794) & River and channel & Omnivore & $8(1.22)$ & $20 \pm 3.77$ \\
\hline Leporinus lacustris Campos, 1945 & River, channel, conlag and disclag & Herbivore & $12(1.83)$ & $14 \pm 1.89$ \\
\hline Schizodon borellii (Boulenger, 1900) & Channel, conlag and disclag & Herbivore & $19(2.90)$ & $24 \pm 2.65$ \\
\hline \multicolumn{5}{|l|}{ Characidae } \\
\hline Astyanax altiparanae Garutti \& Britski, 2000 & River, channel, conlag and disclag & Insectivore & $49(7.50)$ & $6 \pm 6.99$ \\
\hline Astyanax fasciatus (Cuvier, 1819) & River and conlag & Insectivore & $6(0.91)$ & $8 \pm 0.67$ \\
\hline Moenkhausia intermedia Eigenmann, 1908 & River, conlag and disclag & Insectivore & $29(4.44)$ & $6 \pm 0.24$ \\
\hline \multicolumn{5}{|l|}{ Characinae } \\
\hline Roeboides descalvadensis Fowler, 1932 & River, conlag and disclag & Insectivore & $59(9.03)$ & $6 \pm 0.60$ \\
\hline \multicolumn{5}{|l|}{ Serrasalminae } \\
\hline Serrasalmus marginatus Valenciennes, 1837 & River, channel, conlag and disclag & Piscivore & $62(9.49)$ & $15 \pm 2.99$ \\
\hline \multicolumn{5}{|l|}{ Curimatidae } \\
\hline Cyphocharax modestus (Fernández-Yépez, 1948) & Disclag & Detritivore & $4(0.61)$ & $8 \pm 0.68$ \\
\hline Cyphocharax nagelii (Steindachner, 1881) & Conlag and disclag & Detritivore & $3(0.45)$ & $10 \pm 2.63$ \\
\hline Steindachnerina brevipinna (Eigenmann \& Eigenmann, 1889) & River and conlag & Detritivore & $20(3.06)$ & $8 \pm 1.56$ \\
\hline Steindachnerina insculpta (Fernández-Yépez, 1948) & River and conlag & Detritivore & $19(2.90)$ & $10 \pm 1.98$ \\
\hline \multicolumn{5}{|l|}{ Cynodontidae } \\
\hline Rhaphiodon vulpinus Agassiz, 1829 & River and channel & Piscivore & $3(0.45)$ & $35 \pm 1.21$ \\
\hline \multicolumn{5}{|l|}{ Erythrinidae } \\
\hline Hoplerythrinus unitaeniatus (Spix \& Agassiz, 1829) & Channel and conlag & Piscivore & $11(1.68)$ & $20 \pm 1.55$ \\
\hline Hoplias aff. malabaricus (Bloch, 1794) & River, channel, conlag and disclag & Piscivore & $59(9.03)$ & $24 \pm 8.20$ \\
\hline Parodontidae & & & & \\
\hline Apareiodon affinis (Steindachner, 1879) & River & Detritivore & $15(2.29)$ & $10 \pm 1.20$ \\
\hline Prochilodontidae & & & & \\
\hline Prochilodus lineatus (Valenciennes, 1836) & River, channel, conlag and disclag & Detritivore & $9(1.37)$ & $25 \pm 5.37$ \\
\hline Perciformes & & & & \\
\hline Cichlidae & & & & \\
\hline Astronotinae & & & & \\
\hline Astronotus crassipinnis (Heckel, 1840) & Channel and conlag & Piscivore & $3(0.45)$ & $22 \pm 2.29$ \\
\hline Cichlinae & & & & \\
\hline Crenicichla britskii Kullander, 1982 & River, channel and disclag & Insectivore & $4(0.61)$ & $11 \pm 2.51$ \\
\hline Geophaginae & & & & \\
\hline Satanoperca pappaterra (Heckel, 1840) & Channel and conlag & Invertivore & $4(0.61)$ & $12 \pm 0.96$ \\
\hline Sciaenidae & & & & \\
\hline Plagioscion squamosissimus (Heckel, 1840) & River and conlag & Piscivore & $3(0.45)$ & $28 \pm 5.16$ \\
\hline Siluriformes & & & & \\
\hline Auchenipteridae & & & & \\
\hline Auchenipterus osteomystax (Miranda Ribeiro, 1918) & River, channel and conlag & Insectivore & $19(2.90)$ & $20 \pm 2.43$ \\
\hline Trachelyopterus galeatus (Linnaeus, 1766) & River, channel, conlag. and disclag & Omnivore & $36(5.51)$ & $14 \pm 1.51$ \\
\hline Callichthyidae & & & & \\
\hline Hoplosternum littorale (Hancock, 1828) & Channel and disclag & Invertivore & $10(1.53)$ & $13 \pm 2.63$ \\
\hline Doradidae & & & & \\
\hline Trachydoras paraguayensis (Eigenmann \& Ward, 1907) & Conlag & Invertivore & $11(1.68)$ & $9 \pm 0.95$ \\
\hline Loricariidae & & & & \\
\hline Loricariinae & & & & \\
\hline Loricariichthys platymetopon Isbrücker \& Nijssen, 1979 & River, channel, conlag and disclag & Detritivore & $106(16.23)$ & $21 \pm 3.85$ \\
\hline Hypostominae & & & & \\
\hline Hypostomus ancistroides (Ihering, 1911) & Channel and disclag & Detritivore & $5(0.76)$ & $16 \pm 1.99$ \\
\hline Hypostomus regani (Ihering, 1905) & River & Detritivore & $6(0.91)$ & $15 \pm 4.37$ \\
\hline Hypostomus sp. & Channel & Detritivore & $5(0.76)$ & $14 \pm 1.59$ \\
\hline Pterigoplichthys ambrosettii (Holmberg, 1893) & River, channel, conlag and disclag & Detritivore & $24(3.67)$ & $31 \pm 4.20$ \\
\hline Rhinelepis aspera Spix \& Agassiz, 1829 & Channel & Detritivore & $12(1.83)$ & $29 \pm 3.54$ \\
\hline Pimelodidae & & & & \\
\hline Iheringichthys labrosus (Lütken, 1874) & River and conlag & Invertivore & $5(0.76)$ & $16 \pm 2.30$ \\
\hline Pimelodus maculatus La Cépède, 1803 & Channel and conlag & Omnivore & $3(0.45)$ & $18 \pm 4.11$ \\
\hline Pseudoplatystoma corruscans (Spix \& Agassiz, 1829) & River, channel and conlag & Piscivore & $3(0.45)$ & $58 \pm 10.52$ \\
\hline
\end{tabular}


Table 3. Mantel test comparing morphological distance matrix (Euclidian Distances between the ecomorphological indices) with the trophic (guilds), spatial (habitat types) and phylogenetic (taxonomic distances) structures matrices. Partial Mantel test comparing residual matrices of the morphological distances (Euclidian Distances between the ecomorphological indices) on the phylogenetic structure (taxonomic distance) with the residual matrices of the trophic (guilds) and spatial (habitat types) structures, also considering phylogenetic structure as independent variable. The probabilities bellow 0.05 are marked in bold.

\begin{tabular}{lcc}
\hline & $\begin{array}{c}p \\
\mathrm{Z}\end{array}$ & $\begin{array}{c}p \\
\left(\mathrm{Z}_{\text {random }} \leq \mathrm{Z}_{\text {observed }}\right)\end{array}$ \\
\hline Mantel test & $\mathbf{0 . 0 3 8}$ \\
$\quad$ morphology x trophic structure & -0.098 & 0.937 \\
$\quad$ morphology x spatial structure & 0.112 & 0.962 \\
$\quad$ morphology x phylogenetic structure & 0.105 & 0.938 \\
Partial Mantel test & & $\mathbf{0 . 0 1 7}$ \\
$\quad$ residuals (morphology x phylogeny) x residuals (trophic guilds x phylogeny) & -0.137 & $\mathbf{0 . 0 1 3}$ \\
$\quad$ residuals (morphology x phylogeny) x residuals (habitat x phylogeny) & 0.109 & 0.906 \\
\hline
\end{tabular}

In order to reveal these interrelationships, partial correlations were calculated using the partial Mantel test, which indicated that the body shape of the fish is influenced by trophic structure $(p=0.01)$, even when the effect of phylogeny is controlled, while the spatial structure did no revealed significant effect ( $p=0.09$; Table 3$)$. This indicates that the body shape of fishes on the upper Paraná River floodplain is a good predictor of the assemblage trophic structure.

Patterns of interspecific ecomorphological diversification. The PCA revealed the formation of four significant axes according to the broken stick model (Table 4). The first two axes explained $46.57 \%$ of the total variation in the ecomorphological space and the indices that presented the highest correlation values were selected for interpretation.

Although the third and fourth axes were significant (percentage of explained variability: PC $3=12.06 \%$; PC $4=$ $10.23 \%$ ), they did not reveal additional information about the ecomorphological diversification patterns of the floodplain fish assemblage. Figures 3, 4 and 5 present the distribution of centroids of the species in the multivariate ecomorphological space ordinated by axes 1 and 2 of the PCA and, in the two last the centroids of the species are grouped by trophic guilds and habitat types, respectively.

Species with more positive scores in the first axis show more compressed bodies, more developed anal fins, larger eyes and wider mouths, especially for piscivores like Serrasalmus marginatus, Rhaphiodon vulpinus, Astronotus crassipinnis and insectivores like Roeboides descalvadensis, Astyanax altiparanae, Astyanax fasciatus, Moenkhausia intermedia and Auchenipterus osteomystax (Table 4; Figs. 3, 4).

Species having more depressed bodies, higher head, more dorsal eyes, and more developed caudal peduncles and pelvic fins are found at the other extreme of the ecomorphological gradient exhibiting more negative scores (Table 4; Fig. 3). These characteristics are typical of benthic species as detritivores (loricariids, Apareiodon affinis, Steindachnerina brevipinna and Steindachnerina insculpta) and invertivores (Hoplosternum littorale, Iheringichthys labrosus and Trachydoras paraguayensis), which prefer lotic and semi-lotic (channels) environments (Figs. 4, 5).
Table 4. Pearson correlation coefficients (r) obtained among the ecomorphological indices and the first two axes of the Principal Components Analysis (PCA), applied to the correlation matrix formed by 22 indices of the 35 species analyzed. At the lower level are described the eigenvalue predicted by broken stick model and proportions of the accumulated and explained variability. The indices with higher correlation values were highlighted in bold and selected for interpretation.

\begin{tabular}{lcc}
\hline & \multicolumn{2}{c}{ PCA axes } \\
\cline { 2 - 3 } Ecomorphological indices & r PC 1 & r PC 2 \\
\hline Compression index & $\mathbf{0 . 9 2 9}$ & -0.086 \\
Depression index & 0.447 & -0.173 \\
Relative lenght of caudal peduncule & $\mathbf{- 0 . 8 1 4}$ & $\mathbf{- 0 . 3 6 4}$ \\
Relative height of caudal peduncule & -0.237 & $\mathbf{0 . 6 8 3}$ \\
Relative width of caudal peduncule & $\mathbf{- 0 . 3 9 1}$ & $\mathbf{- 0 . 4 4 7}$ \\
Relative length of head & 0.462 & $\mathbf{0 . 6 1 5}$ \\
Relative height of head & $\mathbf{- 0 . 7 6 1}$ & 0.146 \\
Relative width of head & 0.027 & $\mathbf{- 0 . 2 9 0}$ \\
Relative height of mouth & -0.266 & -0.069 \\
Relative width of mouth & $\mathbf{0 . 7 1 5}$ & 0.083 \\
Protrusion index & 0.561 & 0.105 \\
Eye position & $\mathbf{- 0 . 5 8 8}$ & -0.051 \\
Relative area of eye & $\mathbf{0 . 7 4 5}$ & 0.048 \\
Relative area of dorsal fin & -0.046 & $\mathbf{0 . 6 9 0}$ \\
Relative area of caudal fin & 0.293 & $\mathbf{0 . 8 3 2}$ \\
Aspect ratio of caudal fin & 0.128 & $\mathbf{- 0 . 5 1 4}$ \\
Relative area of anal fin & $\mathbf{0 . 7 7 1}$ & -0.098 \\
Aspect ratio of anal fin & $\mathbf{0 . 7 3 8}$ & $\mathbf{- 0 . 2 9 2}$ \\
Relative area of pectoral fin & -0.047 & $\mathbf{0 . 7 0 8}$ \\
Aspect ratio of pectoral fin & 0.425 & -0.038 \\
Relative area of pelvic fin & $\mathbf{- 0 . 5 7 3}$ & $\mathbf{0 . 5 2 7}$ \\
Aspect ratio of pelvic fin & 0.556 & -0.041 \\
Eigenvalue & 6.58 & 3.65 \\
Predicted eigenvalue: broken-stick & 3.69 & 2.69 \\
Explained variability (\%) & 29.94 & 16.62 \\
Accumulated variability (\%) & 29.94 & 46.57 \\
\hline
\end{tabular}

Species exhibiting a tendency to fusiformity of the body are found near the origin of the axes (Fig. 3). Among them are omnivores Leporinus friderici, Trauchelyopterus galeatus and Pimelodus maculatus, as well as herbivores like Schizodon borellii and Leporinus lacustris (the latter with a tendency for omnivory) (Figs. 3, 4). Therefore, in this region of the gradient there is a clear overlap of species with a more generalist body shape and feeding habit, discriminating the two extreme groups previously mentioned (right: piscivores and insectivores; left: detritivores). 

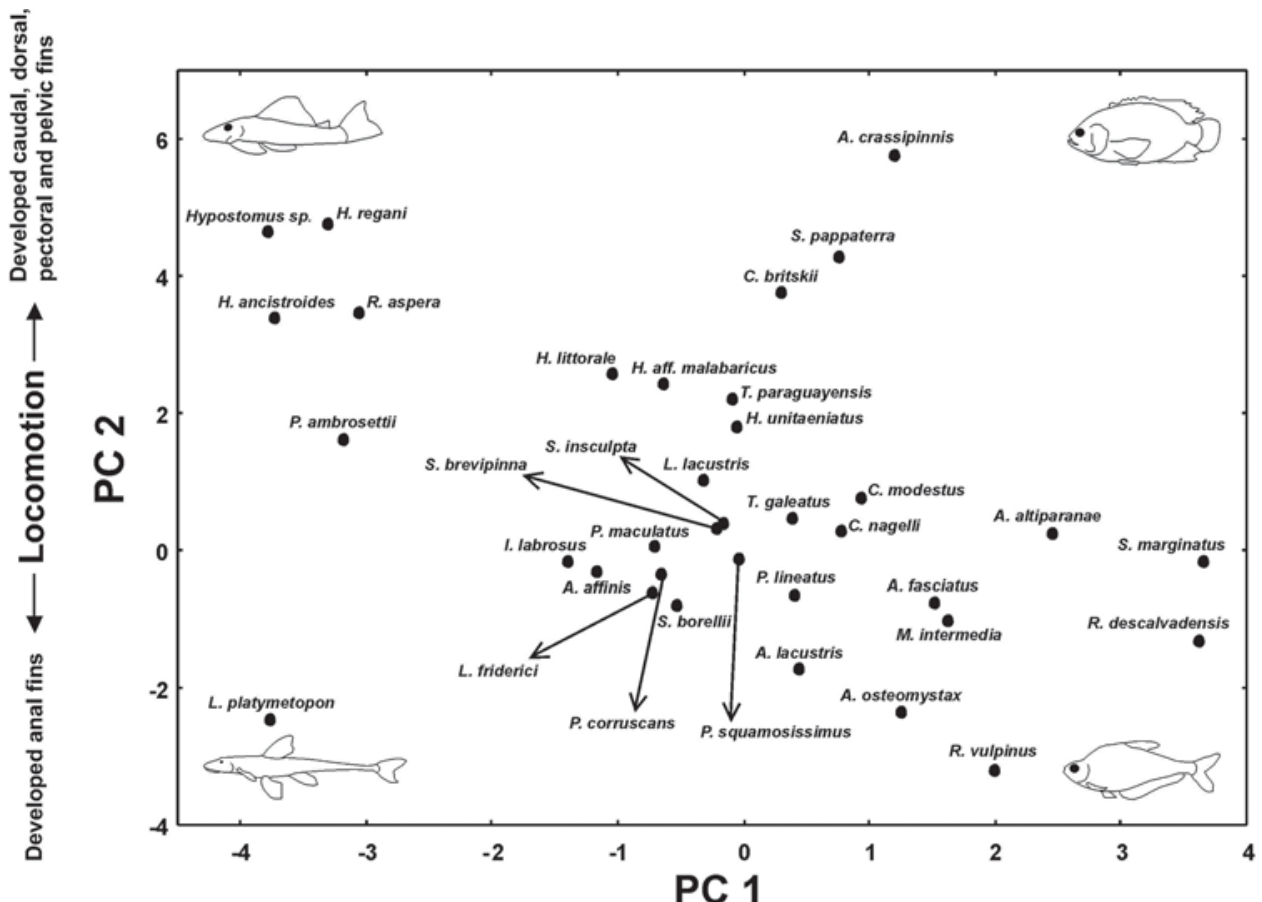

Support and propulsion in the substrate (depressed bodies, more dorsal eyes and more
developed pectoral fins and caudal peduncules)

PC 1

\section{Detritivory and invertivory $\longleftarrow \quad$ Trophic \\ ecology \\ (smaller eyes and mouth)}

\section{Maneuverability}

(more compressed trunk and more developed anal fins)

Fig. 3. Distribution of scores centroids of the 35 species on the first two axes of the Principal Components Analysis (PC 1 and PC 2), applied to the correlation matrix (Pearson) formed by 22 ecomorphological indices.

The second axis of the PCA indicated an ecomorphological gradient mainly influenced by fins, caudal peduncle and head size. The caudal, pectoral, dorsal and pelvic fin areas, as well as the relative height of peduncle and relative length of head, presented the highest positive correlations with this axis, separating a group constituted by cichlids Astronotus crassipinnis, Crenicichla britskii and Satanoperca pappaterra and other by loricariids Hypostomus spp. and Rhinelepis aspera (Table 4; Fig. 3). The aspect ratios of caudal and anal fins, width and length of caudal peduncle and head width have high negative scores. The first two indices characterize the characids, which were segregated from Loricariichthys platymetopon along axis 1 . The other three indices explain the position of L. platymetopon in the multivariate space, with relatively wider and longer peduncles and wider heads (Table 4; Fig. 3).

Prediction of ecomorphotypes. The MANOVA presented significant differences among the ecomorphotypes that compose the trophic guilds (Wilks' $\lambda=0.004 ; \mathrm{F}_{110 ; 3,071}=56.28$; $p<0.001)$ and the habitat types exploited by the assemblage (Wilks' $\lambda=0.492 ; \mathrm{F}_{66 ; 1,876}=7.62 ; p<0.001$ ). The trophic guilds presented more significant differences among themselves than the habitat types, corroborating results revealed by Mantel test.
The models predicted by the CDA showed the ecomorphological indices that most contributed to the discrimination among the trophic guilds and among the habitat types. The first canonical axis of the CDA, applied to the trophic guilds (51\% of explained variability), demonstrated that there was a clear phenotypical segregation of the guilds of piscivores and insectivores, with more positive scores in relation to the others. As in the PCA, the omnivores occupied the center of the ordination. The piscivores and insectivores presented wider mouths, higher values for protrusion and compression indices, and the aspect ratios and relative areas of anal fin. At the other extreme of axis 1 are the detritivores, with longer and wider peduncles, higher heads, larger pelvic fins and dorsal eyes (Table 5; Fig. 6).

On the second axis (28.8\% of explained variability), the piscivores and insectivores are also segregated from the others, but in opposite positions. The piscivores presented longer heads, higher indices of protrusion, higher mouths, larger dorsal fins and aspect ratios of caudal fin, while the insectivores revealed more developed anal fins, eyes relatively upper and larger aspect ratios of pectoral and relative areas of caudal fin (Table 5; Fig. 6).

The CDA model successfully predicted $94.5 \%$ of the component members of the trophic guilds (Table 6). The classification matrix indicated that all the herbivorous were correctly classified, while piscivores, insectivores and 

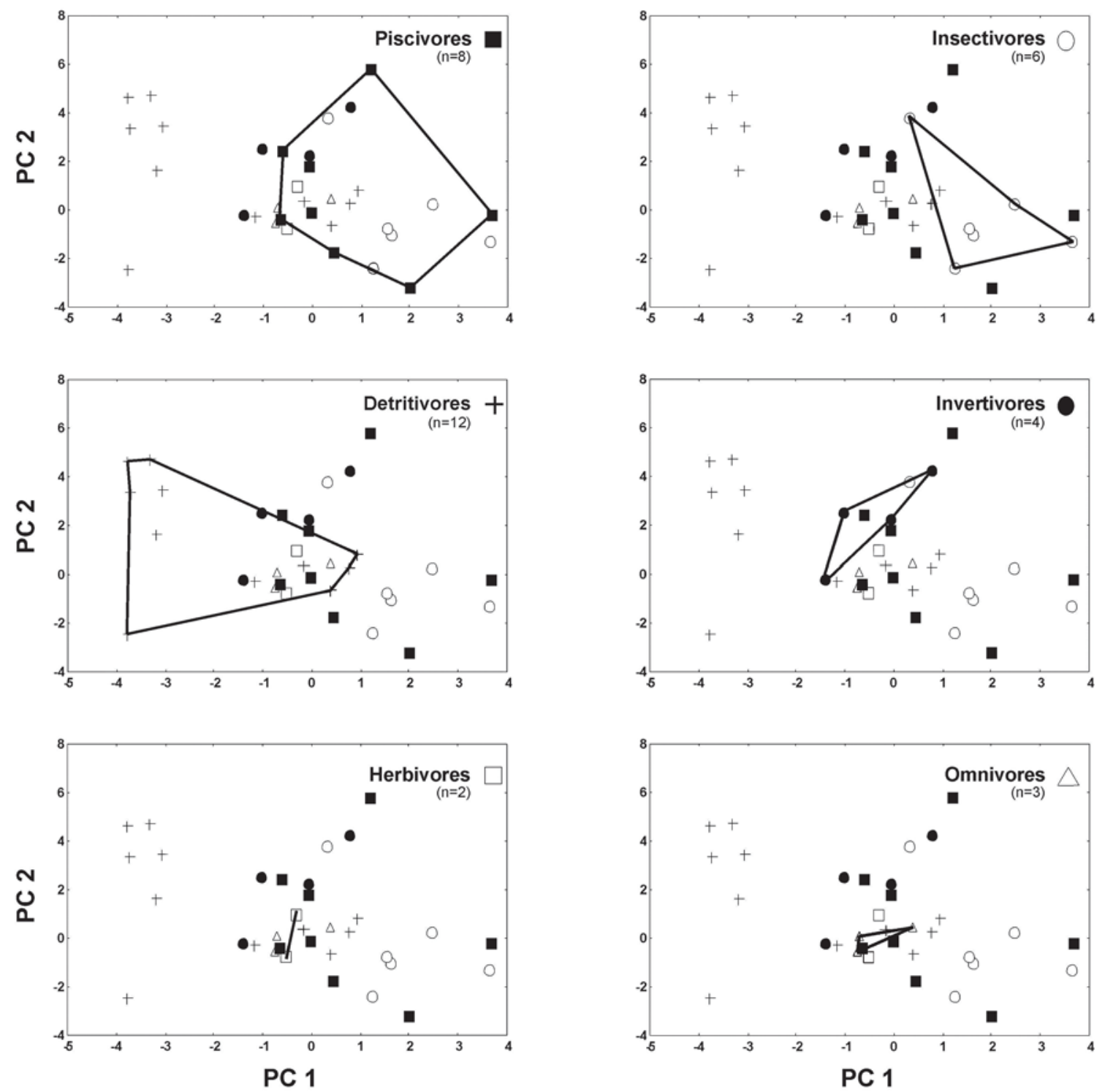

Fig. 4. Distribution of scores centroids of the 35 species on the first two axes of the Principal Components Analysis (PC 1 and PC 2), applied to the correlation matrix (Pearson) formed by 22 ecomorphological indices. Each polygon defines the morphological space occupied by the species that compose the corresponding trophic guild.

detritivores presented higher percentages of correct classification. The lower percentages were attributed to the guilds with high feed overlap, mainly among the omnivores and invertivores.

As regards the habitat types, the first canonical axis $(57.1 \%$ of explained variability) presented a slight ecomorphological segregation of reophilic individuals (scores more negative), with larger eyes and pelvic fins, higher heads and values of the aspect ratio of pectoral fin, while the individuals of habitats more dissimilar to the rivers (channels and connected lagoons; Fig. 7a, b) presented higher and wider mouths, longer heads and larger anal fins (Table 5). On the second canonical axis, individuals of disconnected lagoons demonstrated a slight segregation in relation to those of other habitats by presenting larger anal fin areas, larger eyes, wider heads and more compressed bodies.
The CDA successfully predicted $57.1 \%$ of the component members of the habitat types (Table 7). The a posteriori classification matrix predicted by the CDA model for the habitat types revealed lower percentages of correct classification than the trophic guilds: disconnected lagoons $(61.8 \%)$, connected lagoons $(58.2 \%)$, rivers $(55.1 \%)$ and channels $(51.0 \%)$.

\section{Discussion}

Ecomorphology analyzes the correlations between the body shape of organisms and the environmental factors, such as use of trophic and spatial resources (i.e., ecological performance). However, few studies have tested the predictive ability of these relationships. In this context, any attempt to relate morphology and ecology should answer the following question: do the morphological variables of an organism 


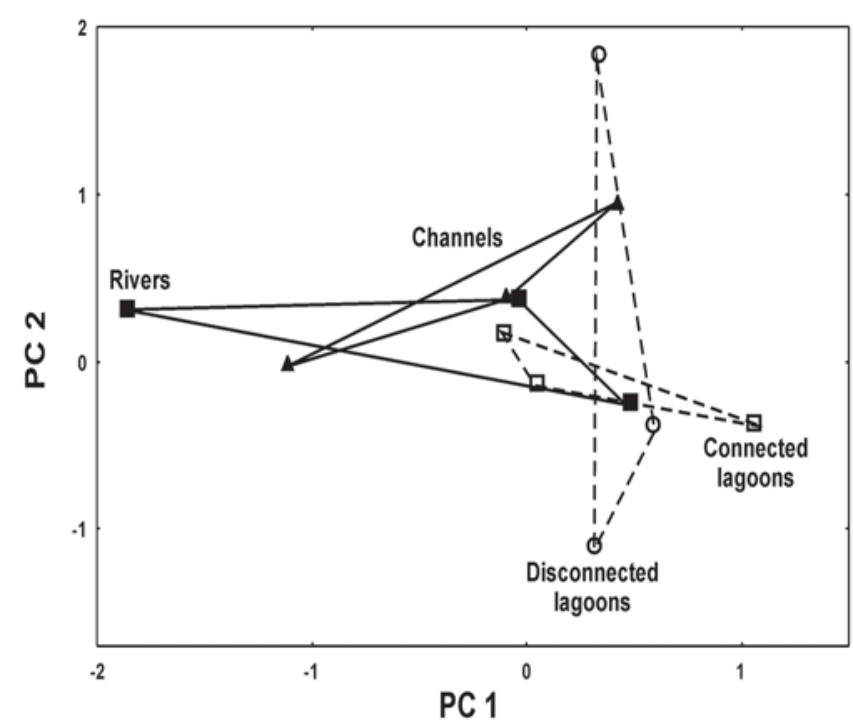

Fig. 5. Distribution of scores centroids of the 35 species grouped by habitat type on the first two axes of the Principal Components Analysis (PC 1 and PC 2), applied to the correlation matrix (Pearson) formed by 22 ecomorphological indices. Each polygon defines the morphological space occupied by the species that exploit the corresponding habitat type.

predict ecological attributes like the food resources that it exploits or the habitat that it occupies? If strong relationships between morphology and ecology are found, it is assumed that the assemblage is ecomorphologically structured, making it possible predictions about the exploitation of environmental resources based on body shape. If these relationships are weak or indistinct, the assemblage may present an ecomorphological structure defined simply by the phylogenetic relationships among the species or present a random structure, i.e., not delimited by morphological adaptations of the organisms to specific niches, but as result of other ecological factors acting together, preventing the formation of an ecomorphological pattern.

In this study, only the null hypothesis of absence of correlation between the morphology of the species and the trophic structure of fish assemblage of the upper Paraná River floodplain was rejected, independent of the phylogenetic relationships. This implies that species morphology is a good predictor of the trophic structure of the assemblage, i.e., if two morphologically similar species were sampled, independent of habitat and taxonomic position, there is a greater probability that they would belong to the same trophic guild.

Patterns of interspecific ecomorphological diversification of upper Paraná River floodplain reveal two tendencies, the first associated with feeding while the second with locomotion. In the first tendency, two extreme groups were observed along the ecomorphological gradient: (i) one with piscivores and insectivores, surface and pelagic species exhibiting more compressed bodies, found more in structured and productive lentic environments (connected and disconnected lagoons) and (ii) the other with detritivores and invertivores, benthic species having more depressed bodies,
Table 5. Pearson correlation coefficients (r) obtained among the ecomorphological indices and the first two canonical axes of Discriminant Analyses, applied to the correlation matrix formed by 22 indices of the 35 species analyzed. At the lower level are described the eigenvalue predicted by broken stick model and proportions of the accumulated and explained variability. The indices with higher correlation values were highlighted in bold and selected for interpretation.

\begin{tabular}{lcccc}
\hline & \multicolumn{4}{c}{ Canonical axes } \\
\cline { 2 - 5 } & Trophic guilds & Habitats \\
\cline { 2 - 5 } Ecomorphological indices & r CA 1 & r CA 2 & r CA 1 & r CA 2 \\
\hline Compression index & $\mathbf{0 . 3 7 9}$ & -0.129 & 0.046 & $\mathbf{0 . 3 6 5}$ \\
Depression index & 0.224 & -0.030 & 0.012 & 0.089 \\
Relative lenght of caudal peduncule & $\mathbf{- 0 . 3 7 5}$ & 0.040 & -0.110 & 0.041 \\
Relative height of caudal peduncule & -0.000 & 0.149 & 0.002 & $\mathbf{- 0 . 5 7 5}$ \\
Relative width of caudal peduncule & $\mathbf{- 0 . 1 1 8}$ & 0.002 & -0.088 & 0.116 \\
Relative length of head & 0.231 & $\mathbf{0 . 3 0 4}$ & $\mathbf{0 . 2 4 6}$ & -0.113 \\
Relative height of head & $\mathbf{- 0 . 2 7 1}$ & 0.049 & $\mathbf{- 0 . 1 5 8}$ & -0.044 \\
Relative width of head & -0.009 & -0.083 & -0.017 & $\mathbf{0 . 4 5 2}$ \\
Relative height of mouth & 0.084 & $\mathbf{0 . 1 8 9}$ & $\mathbf{0 . 3 9 3}$ & -0.013 \\
Relative width of mouth & $\mathbf{0 . 6 1 5}$ & 0.134 & $\mathbf{0 . 2 4 1}$ & 0.209 \\
Protrusion índex & $\mathbf{0 . 4 6 3}$ & $\mathbf{0 . 1 9 2}$ & 0.099 & 0.314 \\
Eye position & $\mathbf{- 0 . 1 5 4}$ & $\mathbf{- 0 . 3 4 3}$ & -0.118 & -0.071 \\
Relative area of eye & 0.261 & 0.073 & $\mathbf{- 0 . 2 8 3}$ & $\mathbf{0 . 4 9 2}$ \\
Relative area of dorsal fin & -0.032 & $\mathbf{0 . 1 5 9}$ & -0.106 & $\mathbf{- 0 . 1 7 6}$ \\
Relative area of caudal fin & 0.131 & $\mathbf{- 0 . 1 2 0}$ & 0.185 & $\mathbf{- 0 . 1 4 2}$ \\
Aspect ratio of caudal fin & -0.059 & $\mathbf{0 . 1 5 9}$ & -0.056 & 0.180 \\
Relative area of anal fin & $\mathbf{0 . 3 1 4}$ & $\mathbf{- 0 . 1 2 0}$ & $\mathbf{0 . 2 3 8}$ & $\mathbf{0 . 6 0 8}$ \\
Aspect ratio of anal fin & $\mathbf{0 . 3 8 3}$ & $\mathbf{- 0 . 4 2 1}$ & 0.023 & 0.310 \\
Relative area of pectoral fin & -0.007 & 0.060 & -0.029 & $\mathbf{- 0 . 1 4 4}$ \\
Aspect ratio of pectoral fin & 0.037 & $\mathbf{- 0 . 2 0 1}$ & $\mathbf{- 0 . 1 1 9}$ & 0.053 \\
Relative area of pelvic fin & $\mathbf{0 . 1 8 8}$ & -0.017 & $\mathbf{- 0 . 1 9 7}$ & $\mathbf{- 0 . 2 1 5}$ \\
Aspect ratio of pelvic fin & 0.118 & -0.111 & 0.013 & 0.195 \\
Eigenvalue & 6.76 & 3.82 & 0.47 & 0.20 \\
Explained variability (\%) & 51.04 & 28.85 & 57.11 & 24.53 \\
Accumulated variability (\%) & 51.04 & 79.88 & 57.11 & 81.64 \\
\hline
\end{tabular}

occurred more in lotic and semi-lotic environments (rivers and channels, respectively). There was a clear overlap of species with more generalist body shape and feeding habits in the center of the multivariate ecomorphological gradient. This regularity in the distribution of the species along the ecomorphological dimensions reflects historical and evolutionary effects of the competitive interactions, having repercussions on the formation of the current pattern of resource sharing on the floodplain, independent of phylogenetic relationships.

In relation to first group, piscivores and insectivores present a greater capacity for maneuverability, exploit more structured lentic environments with greater efficiency, mainly in littoral regions. There is generally a large availability of preferential food resources in these regions for piscivores (small-sized fish and young forms of other species; Oliveira et al., 2001) and insectivores (aquatic insects in different phases of development; Takeda et al., 2003).

Experimental studies have shown that short and compressed fishes (like A. crassipinnis and S. marginatus) present greater maneuverability (Werner, 1977; Gerstner, 1999), a characteristic that is reinforced by the presence of developed anal fins (Breda et al., 2005). Webb et al. (1996) defined maneuverability as the ability of a fish to perform small-angled 


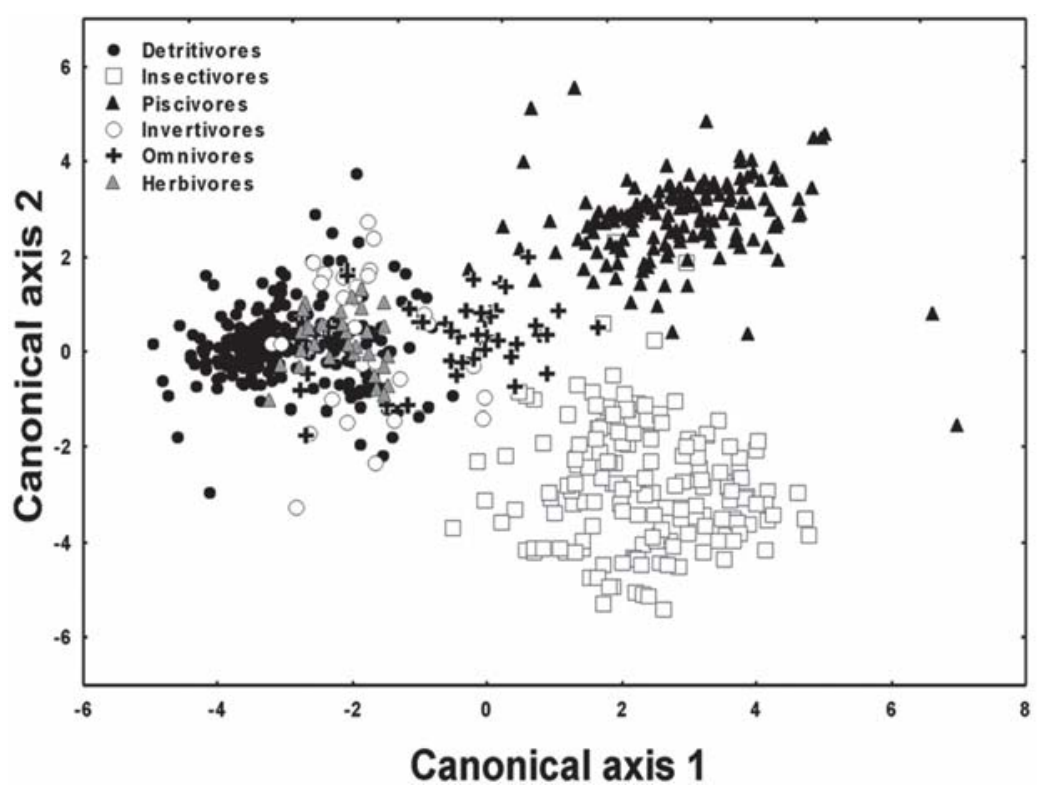

Fig. 6. Diagram of Canonical Discriminant Analysis for the ecomorphological indices of the fish assemblage grouping in trophic guilds in the upper Paraná River floodplain (detritivores, insectivores, piscivores, invertivores, omnivores and herbivores).

quick maneuvers, and Alexander (1967) emphasized that the higher and the shorter the body, the lower the water resistance. Therefore, fishes with compressed bodies performed upward and downward movements with greater agility and tend to present better performance in habitats that are structurally complex and with low current velocity, like sites with an abundance of macrophytes. Neves \& Monteiro (2003) verified that the body of Poecilia vivipara in coastal lagoons of southeastern Brazil is higher in individuals that inhabit regions covered by macrophytes and more fusiform in those that inhabit open regions. A similar pattern was found by Langerhans et al. (2003) for the characid Bryconops caudomaculatus and the cichlid Biotodoma wavrinium in floodplain habitats of the Cinaruco River (Venezuela).

On the other hand, detritivores and invertivores find their preferential food resources in lotic (rivers) and semi-lotic (channels) environments due to their benthic feeding habit (Fugi et al., 1996) and morphological adaptations that allows the exploitation of the substrate to compensate the difficulties caused by the current. Developed caudal peduncles and pectoral fins are fundamental to the stabilization of the body of benthic species in the substrate, as well as in the movement in short distances in lotic and semi-lotic environments.
Armored catfishes (loricariids: Hypostomus spp., Loricariichthys platymetopon, Rhineleps aspera and Pterygoplichthys ambrosettii) are located in this point of the ecomorphological gradient. These species have depressed and low bodies (generally elongated with long peduncles), which are typical of fishes that live in intense current habitats (Hora, 1922; Keast, 1978). The greater difficulty for these fishes exploit rivers with quick current is to remain in the substrate. They suffer the effect of forces of resistance that tend to elevate their body, mainly the net pressure force, which is composed by two components: a lift force, acting normal to the axis of motion, and a drag force, acting along that axis and retarding the motion (Webb, 1974). It results from the more rapid movement of water molecules across the upper surface than the lower surface of the body (Bernoulli effect). However, this effect is eliminated when the fish remains in contact with the substrate, because there is no water pressure underneath its body.

Species with more generalist body shape (fusiform) and feeding habitats (omnivores) are in the center of multivariate ecomorphological gradient. The fusiform body presents the trunk with its maximum height located in the anterior region of the body, low caudal peduncle and high caudal fin that

Table 6. Classification matrix predicted by Canonical Discriminant Analysis (CDA) model for the trophic guilds from upper Paraná River floodplain.

\begin{tabular}{|c|c|c|c|c|c|c|c|c|c|}
\hline \multirow{9}{*}{$\begin{array}{l}\text { ڤे } \\
\Xi \\
0 \\
0 \\
0 \\
0 \\
0 \\
0 \\
0 \\
0 \\
0\end{array}$} & & \multicolumn{6}{|c|}{ Predicted groups by CDA model } & & \\
\hline & & Detritivores & Insectivores & Piscivores & Invertivores & Omnivores & Herbivores & Observed total & Corrected classification (\%) \\
\hline & Detritivores & 215 & 0 & 0 & 6 & 0 & 7 & 228 & 94.3 \\
\hline & Insectivores & 0 & 162 & 4 & 0 & 0 & 0 & 166 & 97.6 \\
\hline & Piscivores & 1 & 1 & 148 & 1 & 0 & 0 & 151 & 98.0 \\
\hline & Invertivores & 5 & 0 & 0 & 24 & 0 & 1 & 30 & 80.0 \\
\hline & Omnivores & 1 & 0 & 0 & 1 & 37 & 8 & 47 & 78.7 \\
\hline & Herbivores & 0 & 0 & 0 & 0 & 0 & 31 & 31 & 100.0 \\
\hline & Predicted total & 222 & 163 & 152 & 32 & 37 & 47 & 653 & 94.5 \\
\hline
\end{tabular}



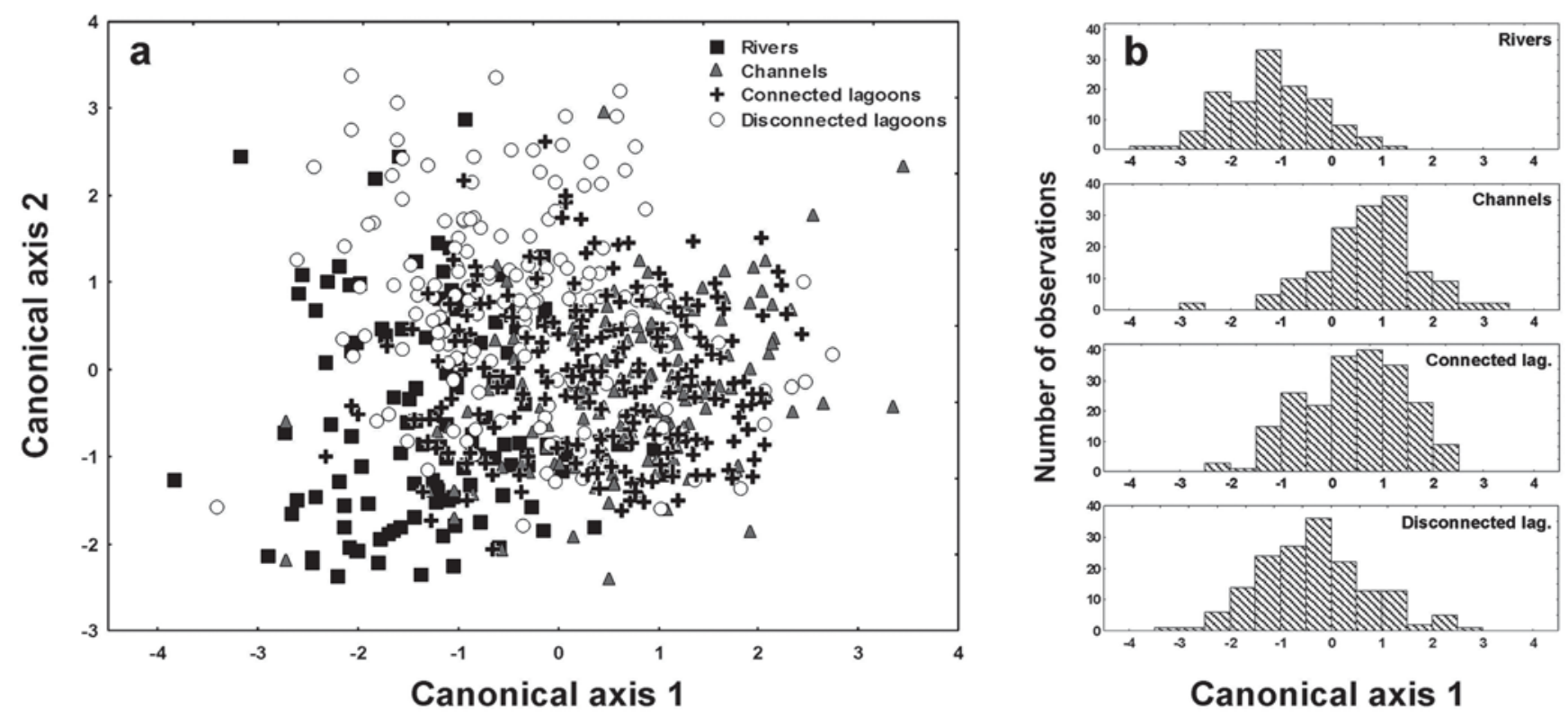

Fig. 7. a) Diagram of Canonical Discriminant Analysis for the ecomorphological indices of the fish assemblage grouping in habitat types in the upper Paraná River floodplain (rivers, channels, connected and disconnected lagoons). b) Histograms with the scores of the habitat types for Canonical axis 1.

reduce the resistances of the aquatic environment which oppose the motion (Gosline, 1971; Webb, 1984). The location of the maximum height in the anterior region of the body avoids its lateral oscillation during propulsion (Webb, 1984). The low peduncle promotes reduction of turbulence caused by the movement of these anterior region and, associated with the superior and inferior extremities of caudal fin outside the turbulence zone, allows the fish more efficient propulsion and maintenance of velocity with lower energetic cost (Gosline, 1971). These characteristics allow that species with fusiform bodies reach a high swimming velocity in obstaclefree pelagic regions (Werner, 1977). Rincón et al. (2007) showed that fusiform morphological specialization (more streamlined individuals) enhances steady swimming performance, but reduces prey-capture success by decreased maneuverability capacity.

The second interspecific ecomorphological diversification tendency indicates a gradient influenced mainly by fins and caudal peduncle, also forming two groups, in which the fins performed distinct functions. In the first group, large dorsal fins of loricariids act as a keel, i.e., they are important in the orientation of motion. This fin avoids that fish rotating on its longitudinal axis when making quick turns (Bond, 1979). Moreover, caudal fins with larger areas help in the propulsion in short distances from a stopped or slow swimming position (Gosline, 1971), and pectoral fins help to maintain the body on the rocky bottoms of lotic and semi-lotic environments, as well as allow quick motions when extended laterally over the substrate and moved abruptly (Gosline, 1994). In the second group, large fins of cichlids are used to increase the capacity of maneuverability, especially the two dorsals - the anterior with spines and the posterior with rays (Helfman et al., 1997) - and the pectorals, which control the vertical body position by generating positive and negative lift forces (Wilga \& Lauder, 1999; Bellwood et al., 2002).

Fish assemblages have frequently been shown to be organized based on habitat (Werner, 1977; Wood \& Bain, 1995; Oliveira et al., 2005; Willis et al., 2005; Hoagstrom \& Berry, 2008). However, the absence of significant correlation observed between morphology and habitat type and the smaller predictive successes for the ecomorphotypes according to the habitats may be related to the dynamics of the floodplain, influenced by pulses that include flood and drought phases (Neiff, 1990). The flood pulse presented a natural tendency of increase in the similarity among environments in relation to their limnological and physiognomic characteristics (Thomaz et al., 2004), as explained by the "flood homogenization hypothesis"

Table 7. Classification matrix predicted by Canonical Discriminant Analysis (CDA) model for the habitat types from upper Paraná River floodplain.

\begin{tabular}{|c|c|c|c|c|c|c|c|}
\hline \multirow{7}{*}{$\begin{array}{l}\text { 号 } \\
0 \\
0 \\
0 \\
0 \\
0 \\
0 \\
0 \\
0 \\
0 \\
0\end{array}$} & & \multicolumn{4}{|c|}{ Predicted groups by CDA model } & & \\
\hline & & Rivers & Channels & Connected lagoons & Disconnected lagoons & Observed total & Corrected classification $(\%)$ \\
\hline & Rivers & 70 & 8 & 29 & 20 & 127 & 55.1 \\
\hline & Channels & 11 & 76 & 7 & 55 & 149 & 51.0 \\
\hline & Connected lagoons & 14 & 21 & 96 & 34 & 165 & 58.2 \\
\hline & Disconnected lagoons & 20 & 30 & 31 & 131 & 212 & 61.8 \\
\hline & Predicted total & 115 & 135 & 163 & 240 & 653 & 57.1 \\
\hline
\end{tabular}


proposed by Thomaz et al. (2007). In this phase, the degree of connectivity becomes high, increasing the chance of a considerable part of the assemblage to exploit different habitats, which allows greater flexibility in the exploitation of the resources of the floodplain, despite its preferences. This high connectivity can produce indistinct limits in the multivariate ecomorphological space, i.e., making overlap possible. This may be responsible for the lower rates of correct classification of these groups.

However, in periods of prolonged drought or anthropological interruption of the pulse (e.g. construction of Porto Primavera Reservoir upstream of the floodplain in 1998 and 1999 and drought in the sampling period of this study in 2000 and 2001), the lagoons presented a strong pattern of environmental heterogeneity, leading to an elevated differentiation of fish assemblage composition, as demonstrated by Oliveira et al. (2001), Okada et al. (2003), Petry et al. (2003) and Agostinho et al. (2004). This may explains the marginally significant correlation found between morphological and spatial structures. Therefore, as described by Shoup \& Hill (1997), in ecomorphological predictions it is necessary to consider the spatio-temporal dynamics of the analyzed environments and identify recent processes of habitat formations, disturbances or introduction of species. Based on the results for the fish assemblage of the Roanoker River (USA), Chan (2001) concluded that morphology will have more success in predicting habitat use by the fish when: (i) more quantitative data from the habitats are used, (ii) the life history of the species is considered, (iii) the selected morphological measurements are strongly associated with the ecological activities developed by the species in the exploitation of the analyzed habitats or microhabitats.

Ecomorphological relationships were used in this study as a tool to predict the members of the ecomorphotypes that compose the trophic guilds and the different types of habitats. The predictive success of the members that compose the ecomorphotypes was greater for the trophic guilds $(94.5 \%)$ than for the habitat types (57.1\%). The most important indices for the prediction of the ecomorphotypes reinforced the results found by the ecomorphological diversification patterns. Three trophic ecomorphotypes were predicted: piscivores, insectivores and detritivores. Piscivores and insectivores were segregated based on the greater capacities for maneuverability (more developed anal fins) and efficiency in the capture of large-sized active prey (size and protrusion of mouth and relative head size). Between the two ecomorphotypes, Piscivores showed more compressed bodies and had larger heads and mouths, while insectivores had more developed eyes and anal fins. On the other hand, the detritivores were segregated mainly by the necessity for support and balance in the exploitation of substrate (more developed pelvic, pectoral and caudal fins). The fact of the more generalist trophic guilds, as omnivores, be intermediate on the ecomorphological gradient among more specialist ecomorphotypes, can to explain their lower rates of correct classification. This generalist form allows the model to include it among the members of other guilds more similar to it.
As regards the assemblage spatial structure, two ecomorphotypes were predicted: fishes that exploit rivers and lagoons. Reophilic fishes have larger eyes, heads, and pelvic and pectoral fins. Larger eyes may be related to greater transparency of this habitat, making it an important attribute for species that chase prey as a food capture strategy (Pankhurst, 1989). However, Herler (2007) verified that gobiid species from deeper regions or shaded habitats, such as coral rock caves, had relatively larger eyes than shallow water species. Mouth size and anal fin development were more important for fishes that exploit the lagoons. In this case, due to the more structured environments, rich in microhabitats, the anal fin is important in the motions involved in predation, escape from predators or for species that use structural heterogeneity during the reproductive process.

The results of the present study refute the idea defended by Douglas \& Matthews (1992) that ecomorphological studies provide valid results only when the analyses are restricted to comparisons within families. Contrary to what these authors conclude, the morphological data were shown to be appropriate indicators of the assemblage structure, i.e., the environmental resource use patterns of the species were not only a result of historical events, but also of biological and ecological processes. Therefore, responding to the inquiry formulated by Douglas \& Matthews (1992), the results of this study make it possible to verify that the influence of phylogeny in trophic relationships, although strong, does not deny the value of ecomorphological analysis in the evaluation of the structure of an assemblage. The segregation of fishes along the trophic axis of the PCA did not simply represent the taxonomic status of the component species. Apparently, the greater diversity of trophic categories within the assemblage and habitats that may be exploited, the lower the influence of phylogeny (Winemiller, 1991; Hugueny \& Pouilly, 1999). As most fishes of the floodplain shows great food flexibility, a reduction in the relative influence of phylogeny on diet or habitat use is expected. But, if the analyses are restricted to the species of a single phylogenetic group, apparently there is a tendency for an increase in the influence of phylogeny on the trophic relationships and the occupation of habitats.

In summary, we concluded that the fish assemblage of the upper Paraná River floodplain was ecomorphologically structured, showing the trophic structure more evident than the spatial, independent of the phylogenetic relationships. This assemblage structure was also confirmed and delimited by the interspecific ecomorphological diversification patterns and by the prediction of the ecomorphotypes related to the trophic guilds and the habitat types. The main ecomorphological patterns of fish assemblage verified in this study were characterized by (i) compressed bodies and developed anal fins for piscivores and insectivores that exploit preferentially lentic and structured habitats, and (ii) depressed bodies and developed caudal, pelvic and pectoral fins for detritivores and invertivores that exploit preferentially lotic and semi-lotic habitats. These patterns consolidate a strong tendency for reliability in the relationship between the 
morphology of the species and their potential niches. In this context, based on the integrative character of ecomorphology, it is possible to identify the ecological preferences of the species and, consequently, consider it as an important tool in analyses of fish assemblage structure.

\section{Acknowledgements}

We are grateful to the Programa de Pós-Graduação em Ecologia de Ambientes Aquáticos Continentais (PEA) and Núcleo de Pesquisas em Limnologia, Ictiologia e Aquicultura (NUPELIA) of the Universidade Estadual de Maringá (UEM) for logistic support. We would like to acknowledge Alberto C. Peret, Ronaldo Angelini, Norma S. Hahn and Ângelo A. Agostinho for constructive comments. We also thank to Carla S. Pavanelli, Cláudio H. Zawadzki and Weferson J. Graça (Museum of Ichthyology of the NUPELIA/UEM) for the identification of species, to librarian Maria S. R. Arita for reference normalization, to Jaime L. L. Pereira and Maria L. Meira by the drawings of Figs. 1 and 2, respectively, and to Maricy R. Vismara and Priscilla D. Negraes by detailed review of English. The suggestions of two anonymous reviewers were also important for improving our manuscript. This research was funded by CNPq/NUPELIA/UEM, through the Long-Term Ecological Research (LTER) Program (site 6). The samplings comply with the current laws of Brazil concerning studies in conservation units. E. F. Oliveira is grateful to CAPES/Ministry of Education/Brazil, L. Breda to CNPq/ Ministry of Science and Technology/Brazil and L.R.S. Paiva to NUPELIA/UEM by scholarships.

\section{Literature Cited}

Agostinho, A. A., L. C. Gomes, S. Veríssimo \& E. K. Okada. 2004. Flood regime, dam regulation and fish in the Upper Paraná River: effects on assemblage attributes, reproduction and recruitment. Reviews in Fish Biology and Fisheries, 14: 11-19.

Agostinho, A. A. \& M. Zalewski. 1996. A Planície Alagável do Alto Rio Paraná: importância e preservação (Upper Paraná River Floodplain: importance and preservation). Maringá, Eduem, $100 \mathrm{p}$.

Albrecht, G. H. 1980. Multivariate analysis and the study of form, with special reference to canonical variate analysis. American Zoologist, 20: 679-693.

Aleev, Y. G. 1969. Function and gross morphology in fish. Jerusalem, H. Mills, 268p.

Alexander, R. McN. 1967. Functional design in fishes. London, Hutchinson University Library, 160p.

Alexander, R. McN. 1988. The scope and aims of functional and ecological morphology. Netherlands Journal of Zoology, 38(1): 3-22.

Autodesk. 2004. AutoCAD: graphic computation. Version 2004. San Rafael, Autodesk, Inc.

Balon, E. K., S. S. Crawford \& A. Lelek. 1986. Fish communities of the Upper Danube River (Germany, Austria) prior to the new Rhein-Main-Donau connection. Environmental Biology of Fishes, 15(4): 243-271.
Barrella, W., A. C. Beaumord \& M. Petrere Jr. 1994. Comparacion de la comunidad de peces de los rios Manso (MT) y Jacare Pepira (SP), Brasil (Comparison between the fish communities of Manso River (MT) and Jacare Pepira River (SP), Brazil). Acta Biologica Venezuelica, 15(2): 11-20.

Beaumord, A. C. \& M. Petrere Jr. 1994. Comunidades de peces del rio Manso, Chapada dos Guimaraes, MT, Brasil (Fish Communities of Manso River, Chapada dos Guimaraes, MT, Brazil). Acta Biologica Venezuelica, 15(2): 21-35.

Bellwood, D. R., P. C. Wainwright, C. J. Fulton \& A. Hoey. 2002. Assembly rules and functional groups at global biogeographical scales. Functional Ecology, 16: 557-562.

Blake, R. W. 2004. Fish functional design and swimming performance. Journal of Fish Biology, 65(5): 1193-1222.

Bock, W. J. 1999. Functional and evolutionary explanations in morphology. Netherlands Journal of Zoology, 49(1): 45-65.

Bond, C. E. 1979. Biology of Fishes. Philadelphia, Saunders College Publishing, 514p.

Bonetto, A. A. 1986. The Paraná River system. Pp. 541-555. In: Davies, B. R. \& K. F. Walker (Eds.). The Ecology of River Systems. Dordrecht, Dr. W. Junk Publishers, 793p.

Breda, L. 2005. Ecomorfologia de Astyanax altiparanae, Moenkhausia intermedia, Roeboides paranensis e Serrasalmus marginatus (Osteichthyes-Characidae) da planície alagável do alto rio Paraná, Brasil: variação inter e intra-específica. Unpublished Ph.D. Dissertation, Universidade Estadual de Maringá, Maringá, 33p.

Breda, L., E. F. Oliveira \& E. Goulart. 2005. Ecomorfologia de locomoção de peixes com enfoque para espécies neotropicais. Acta Scientiarum: Biological Sciences, 27(4): 371-381.

Chan, M. D. 2001. Fish ecomorphology: predicting habitat preferences of stream fishes from their body shape. Unpublished Ph.D. Thesis, Virginia Polytechnic Institute and State University, Virginia, 252p.

Casatti, L. \& R. M. C. Castro. 2006. Testing the ecomorphological hypothesis in a headwater riffles fish assemblage of the rio São Francisco, southeastern Brazil. Neotropical Ichthyology, 4(2): 203-214.

Cochran-Biederman, J. L. \& K. O. Winemiller. 2010. Relationships among habitat, ecomorphology and diets of cichlids in the Bladen River, Belize. Environmental Biology of Fishes, 88: 143-152.

Costa, C. \& S. Cataudella. 2007. Relationship between shape and trophic ecology of selected species of Sparids of the Caprolace coastal lagoon (Central Tyrrhenian sea). Environmental Biology of Fishes, 78: 115-123.

Delariva, R. L. \& A. A. Agostinho. 2001. Relationship between morphology and diets of six neotropical loricariids. Journal of Fish Biology, 58: 832-847.

Douglas, M. E. \& W. J. Matthews. 1992. Does morphology predict ecology? Hypothesis testing within a freshwater stream fish assemblage. Oikos, 65: 213-224.

Felley, J. D. 1984. Multivariate identification of morphologicalenvironmental relationships within the Cyprinidae (Pisces). Copeia, 1984(2): 442-455.

Freire, A. G. \& A. A. Agostinho. 2001. Ecomorfologia de oito espécies dominantes da ictiofauna do reservatório de Itaipu (Paraná/ Brasil). Acta Limnologica Brasiliensia, 13(1): 1-9.

Fugi, R., N. S. Hahn \& A. A. Agostinho. 1996. Feeding styles of five species of bottom-feeding fishes of the High Paraná River. Environmental Biology of Fishes, 46: 297-307.

Gatz Jr., A. J. 1979. Ecological morphology of freshwater stream fishes. Tulane Studies in Zoology and Botany, 21(2): 91-124. 
Gerstner, C. L. 1999. Maneuverability of four species of coral-reef fish that differ in body and pectoral-fin morphology. Canadian Journal Zoology, 77: 1102-1110.

Gosline, W. A. 1971. Functional Morphology and Classification of Teleostean Fishes. Honolulu, University Press of Hawaii, 208p.

Gosline, W. A. 1994. Function and structure in the paired fins of scorpaeniform fishes. Environmental Biology of Fishes, 40: 219-226.

Gotelli, N. J. \& A. M. Ellison. 2004. A Primer of Ecological Statistics. Sunderland, Sinauer Associates, 510p.

Graça, W. J. \& C. S. Pavanelli. 2007. Peixes da planície de inundação do alto rio Paraná e áreas adjacentes. Maringá, Eduem, 241p.

Hahn, N. S., R. Fugi \& I. F. Andrian. 2004. Trophic ecology of the fish assemblages. Pp. 247-269. In: Thomaz, S. M., A. A. Agostinho \& N. S. Hahn (Eds.). The Upper Paraná River and its Floodplain: physical aspects, ecology and conservation. Leiden, Backhuys Publishers, 393p.

Helfman, G. S., B. B. Collete \& D. E. Facey. 1997. Functional morphology of locomotion and feeding. Pp. 101-106. In: Helfman, G. S., B. B. Collete \& D. E. Facey (Eds.). The Diversity of Fishes. Malden, Blackwell Science, 528p.

Herler, J. 2007. Microhabitats and ecomorphology of coral- and coral rock-associated gobiid fish (Teleostei: Gobiidae) in the northern Red Sea. Marine Ecology, 28(Suppl. 1): 82-94.

Hoagstrom, C. W. \& C. R. Berry. 2008. Morphological diversity among fishes in a Great Plains river drainage. Hydrobiologia, 596: 367-386.

Hora, S. L. 1922. Structural modifications in the fish of mountain torrents. Records of the Indian Museum, 24: 31-61.

Hugueny, B. \& M. Pouilly. 1999. Morphological correlates of diet in an assemblage of West African freshwater fishes. Journal of Fish Biology, 54: 1310-1325.

Jackson, D. A. 1993. Stopping rules in principal components analysis: a comparison of heuristical and statistical approaches. Ecology, 74(8): 2204-2214.

Johnson, D. E. 1998. Applied Multivariate Methods for Data Analysts. Pacific Grove, ITP, 567p.

Keast, A. 1978. Trophic and spatial interrelationships in the fish species of an Ontario temperate lake. Environmental Biology of Fishes, 3(1): 7-31.

Keast, A. \& D. Webb. 1966. Mouth and body form relative to feeding ecology in the fish fauna of a small lake, Lake Opinicon, Ontario. Journal of the Fisheries Research Board of Canada, 23(12): 1845-1874.

Langerhans, R. B., C. A. Layman, A. K. Langerhans \& T. J. Dewitt. 2003. Habitat-associated morphological divergence in two Neotropical fish species. Biological Journal of the Linnean Society, 80: 689-698.

Lauder, G. V. 1989. Caudal fin locomotion in ray-finned fishes: historical and functional analyses. American Zoologist, 29(1): 85-102.

Legendre, P. \& L. Legendre. 1998. Numerical Ecology. Amsterdam, Elsevier, 853p.

Lindsey, C. C. 1978. Form, function, and locomotory habits in fish. Pp. 1-100. In: Hoar, W. S. \& D. J. Randall (Eds.). Fish Physiology, v. 7. New York, Academic Press, 576p.

Maldonado, E., N. Hubert, P. Sagnes \& B. De Mérona. 2009. Morphology-diet relationships in four killifishes (Teleostei, Cyprinodontidae, Orestias) from Lake Titicaca. Journal of Fish Biology, 74: 502-520.

McCune, B. \& M. J. Mefford. 1999. PC-ORD: multivariate analysis of ecological data. Version 4.01. Oregon, MjM Software Design, $47 \mathrm{p}$.
Motta, P. J., S. F. Norton \& J. J. Luczkovich. 1995. Perspectives on the ecomorphology of bony fishes. Environmental Biology of Fishes, 44(1-3): 11-20.

Neiff, J. J. 1990. Ideas para la interpretacion ecologica del Parana. Interciencia, 15(6): 424-441.

Neves, F. M. \& L. R. Monteiro. 2003. Body shape and size divergence among populations of Poecilia vivipara in coastal lagoons of south-eastern Brazil. Journal of Fish Biology, 63: 928-941.

Okada, E. K., A. A. Agostinho, M. Petrere Jr. \& T. Penczak. 2003. Factors affecting fish diversity and abundance in drying ponds and lagoons in the Upper Paraná River Basin, Brazil. Ecohydrology \& Hydrobiology, 3(1): 97-110.

Oliveira, E. F., E. A. Luiz, A. A. Agostinho \& E. Benedito-Cecílio. 2001. Fish assemblages in littoral areas of the Upper Paraná River floodplain, Brazil. Acta Scientiarum, 23(2): 369-376.

Oliveira, E. F., C. V. Minte-Vera \& E. Goulart. 2005. Structure of fish assemblages along spatial gradients in a deep subtropical reservoir (Itaipu Reservoir, Brazil-Paraguay border). Environmental Biology of Fishes, 72: 283-304.

Pakkasmaa, S., E. Ranta \& J. Piironen. 1998. A morphometric study on four land-locked salmonid species. Annales Zoologici Fennici, 35: $131-140$.

Pankhurst, N. W. 1989. The relationship of ocular morphology to feeding modes and activity periods in shallow marine teleosts from New Zealand. Environmental Biology of Fishes, 26: 201-211.

Peretti, D. \& I. F. Andrian. 2004. Trophic structure of fish assemblages in five permanent lagoons of the high Paraná River floodplain, Brazil. Environmental Biology of Fishes, 71: $95-103$.

Peterson, M. S. \& S. J. VanderKooy. 1996. Preservation-induced changes in morphometrics of fishes: influence on prey sizechoice in juvenile walleye, Stizostedion vitreum (Mitchill). Ecology of Freshwater Fish, 5: 133-139.

Petry, A. C., A. A. Agostinho \& L. C. Gomes. 2003. Fish assemblages of tropical floodplain lagoons: exploring the role of connectivity in a dry year. Neotropical Ichthyology, 1(2): 111-119.

Piet, G. J. 1998. Ecomorphology of a size-structured tropical freshwater fish community. Environmental Biology of Fishes, 51: 67-86.

Pouilly, M., F. Lino, J. -G. Bretenoux \& C. Rosales. 2003. Dietarymorphological relationships in a fish assemblage of the Bolivian Amazonian floodplain. Journal of Fish Biology, 62: 1137-1158.

Reis, R. E., S. O. Kullander \& C. J. Ferraris Jr. (Org.). 2003. Check list of the freshwater fishes of South and Central America. Porto Alegre, Edipucrs, 729p.

Ricklefs, R. E. \& D. B. Miles. 1994. Ecological and evolutionary inferences from morphology: an ecological perspective. Pp. 1341. In: Wainwright, P. C. \& S. M. Reilly (Eds.). Ecological Morphology: integrative organismal biology. Chicago, University of Chicago Press, $367 \mathrm{p}$.

Rincón, P. A., M. Bastir \& G. D. Grossman. 2007. Form and performance: body shape and prey-capture success in four driftfeeding minnows. Oecologia, 152: 345-355.

Rohlf, F. J. 1989. NTSYS-pc: numerical taxonomy and multivariate analysis system. Version 1.50. New York, Exeter Publishing, $199 \mathrm{p}$.

Russo, T., C. Costa \& S. Cataudella. 2007. Correspondence between shape and feeding habit changes throughout ontogeny of gilthead sea bream Sparus aurata L., 1758. Journal of Fish Biology, 71: 629-656. 
Sagnes, P., P. Gaudin \& B. Statzner. 1997. Shifts in morphometrics and their relation to hydrodynamic potential and habitat use during grayling ontogenesis. Journal of Fish Biology, 50: 846-858.

Shoup, D. E. \& L. G. Hill. 1997. Ecomorphological diet predictions: an assessment using inland silverside (Menidia beryllina) and longear sunfish (Lepomis megalotis) from Lake Texoma. Hydrobiologia, 350: 87-98.

Smouse, P. E., J. C. Long \& R. R. Sokal. 1986. Multiple regression and correlation extensions of the Mantel Test of matrix correspondence. Systematic Zoology, 35(4): 627-632.

Souza Filho, E. E. \& J. C. Stevaux. 2004. Geology and geomorphology of the Baía-Curutuba-Ivinheima River complex. Pp. 1-29. In: Thomaz, S. M., A. A. Agostinho \& N. S. Hahn (Eds.). The Upper Paraná River and its Floodplain: physical aspects, ecology and conservation. Leiden, Backhuys Publishers, 393p.

StatSoft. 2003. Statistica for Windows (computer program manual). Version 6.0. Tulsa, StatSoft, Inc.

Suzuki, H. I., A. E. A. de M. Vazzoler, E. E. Marques, M. A. Perez Lizama \& P. Inada. 2004. Reproductive ecology of the fish assemblages. Pp. 271-291. In: Thomaz, S. M., A. A. Agostinho \& N. S. Hahn (Eds.). The Upper Paraná River and its Floodplain: physical aspects, ecology and conservation. Leiden, Backhuys Publishers, 393p.

Takeda, A. M., G. M. Souza-Franco, S. M. Melo \& A. Monkolski. 2003. Invertebrados associados às macrófitas aquáticas da planície de inundação do alto rio Paraná (Brasil). Pp. 243-260. In: Thomaz, S. M. \& L. M. Bini (Eds.). Ecologia e Manejo de Macrófitas Aquáticas. Maringá, Eduem, 341p.

Thomaz, S. M., L. M. Bini \& R. L. Bozelli. 2007. Floods increase similarity among aquatic habitats in river-floodplain systems. Hydrobiologia, 579: 1-13.

Thomaz, S. M., T. A. Pagioro, L. M. Bini, M. C. Roberto \& R. R. A. Rocha. 2004. Limnological characterization of the aquatic environments and the influence of hydrometric levels. Pp. 75102. In: Thomaz, S. M., A. A. Agostinho \& N. S. Hahn (Eds.). The Upper Paraná River and its Floodplain: physical aspects, ecology and conservation. Leiden, Backhuys Publishers, 393p.

Vazzoler, A. E. A. de M. 1996. Biologia da Reprodução de Peixes Teleósteos: teoria e prática. Maringá, Eduem, 169p.

Videler, J. J. 1993. Fish Swimming. London, Chapman \& Hall, 260p.
Wainwright, P. C., D. R. Bellwood \& M. W. Westneat. 2002. Ecomorphology of locomotion in labrid fishes. Environmental Biology of Fishes, 65: 47-62.

Ward-Campbell, B. M. S., F. W. H. Beamish \& C. Kongchaiya. 2005. Morphological characteristics in relation to diet in five coexisting Thai fish species. Journal of Fish Biology, 67: 1266-1279.

Watson, D. J. \& E. K. Balon. 1984. Ecomorphological analysis of fish taxocenes in rainforest streams of northern Borneo. Journal of Fish Biology, 25: 371-384.

Webb, P. W. 1974. Hydrodynamics and energetics of fish propulsion. Bulletin Fisheries Research Board Canada, 190: 1-159.

Webb, P. W. 1980. Function of the caudal fin in early fishes. Copeia, 1980(3): 559-562.

Webb, P. W. 1984. Form and function in fish swimming. Scientific American, 251(1): 58-68.

Webb, P. W., G. D. Laliberte \& A. J. Schrank. 1996. Does body and fin form affect the maneuverability of fish traversing vertical and horizontal slits? Environmental Biology of Fishes, 46: 7-14.

Werner, E. E. 1977. Species packing and niche complementarity in three sunfishes. American Naturalist, 111(979): 553-578.

Wikramanayake, E. D. 1990. Ecomorphology and biogeography of a tropical stream fish assemblage: evolution of assemblage structure. Ecology, 71(5): 1756-1764.

Wilga, C. D. \& G. V. Lauder. 1999. Locomotion in sturgeon: function of the pectoral fins. Journal of Experimental Biology, 202: 24132432.

Willis, S. C., K. O. Winemiller \& H. Lopez-Fernandez. 2005. Habitat structural complexity and morphological diversity of fish assemblages in a Neotropical floodplain river. Oecologia, 142: 284-295.

Winemiller, K. O. 1991. Ecomorphological diversification in lowland freshwater fish assemblages from five biotic regions. Ecological Monographs, 61(4): 343-365.

Wood, B. M. \& M. B. Bain. 1995. Morphology and microhabitat use in stream fish. Canadian Journal of Fisheries and Aquatic Science, 52: 1487-1498.

Xie, S., Y. Cui \& Z. Li. 2001. Dietary-morphological relationships of fishes in Liangzi Lake, China. Journal of Fish Biology, 58: 1714-1729. 
Appendix 1. Description of the ecomorphological indices and their ecological explanations.

\begin{tabular}{|c|c|c|}
\hline \multicolumn{3}{|r|}{ Ecomorphological indices } \\
\hline Indices & Formulas & Explanations \\
\hline 1. Compression index & $\mathrm{CI}=\mathrm{MBH} / \mathrm{MBW}$ & $\begin{array}{l}\text { Higher values indicate lateral compression of the fish, which is expected for fish that } \\
\text { explore habitats with slower water velocity habitats (Gatz Jr., 1979; Watson \& Balon, } \\
\text { 1984). }\end{array}$ \\
\hline 2. Depression index & $\mathrm{DI}=\mathrm{BMH} / \mathrm{MBH}$ & $\begin{array}{l}\text { Lower values are associated with fish that explore habitats closer to bottom habitats (Hora } \\
\text { 1922; Watson \& Balon, 1984). }\end{array}$ \\
\hline $\begin{array}{l}\text { 3. Relative lenght of } \\
\text { caudal peduncule }\end{array}$ & $\mathrm{RLPd}=\mathrm{CPdL} / \mathrm{SL}$ & $\begin{array}{l}\text { Fishes with long caudal peduncle are goods swimmers. However, fishes adapted to rapid } \\
\text { water flow, but no necessarily nektonic as armored catfishes, also presented long caudal } \\
\text { peduncules in function of propulsion in short distances (Hora, 1922; Watson \& Balon, } \\
\text { 1984; Winemiller, 1991). }\end{array}$ \\
\hline $\begin{array}{l}\text { 4. Relative height of } \\
\text { caudal peduncule }\end{array}$ & $\mathrm{RHPd}=\mathrm{CPdH} / \mathrm{MBH}$ & Lower values indicate greater maneuverability potential (Winemiller, 1991). \\
\hline $\begin{array}{l}\text { 5. Relative width of } \\
\text { caudal peduncule }\end{array}$ & $\mathrm{RWPd}=\mathrm{CPdW} / \mathrm{MBW}$ & Higher relative values indicate better continuous swimmers (Winemiller, 1991). \\
\hline 6. Relative lenght of head & $\mathrm{RLHd}=\mathrm{HdL} / \mathrm{SL}$ & $\begin{array}{l}\text { Larger relative values of head length are found in fishes which feed of larger prey. This } \\
\text { index should be larger for piscivores (Watson \& Balon, 1984; Winemiller, 1991; Barrella et } \\
\text { al., 1994; Pouilly et al., 2003; Willis et al., 2005). }\end{array}$ \\
\hline 7. Relative height of head & $\mathrm{RHHd}=\mathrm{HdH} / \mathrm{MBH}$ & $\begin{array}{l}\text { Larger relative values of head height are found in fishes which feed of larger prey. Larger } \\
\text { values for this index are expected for piscivores (Winemiller, 1991; Willis et al., 2005). }\end{array}$ \\
\hline 8. Relative width of head & $\mathrm{RWHd}=\mathrm{HdW} / \mathrm{MBW}$ & $\begin{array}{l}\text { Larger relative values of head width are found in fishes which feed of larger prey. Larger } \\
\text { values for this index are expected for piscivores (Winemiller, 1991; Willis et al., 2005). }\end{array}$ \\
\hline 9. Relative height of mouth & $\mathrm{RHM}=\mathrm{MH} / \mathrm{MBH}$ & $\begin{array}{l}\text { Relative mouth height allows to infer over the relative size of the prey (Gatz Jr., 1979; } \\
\text { Winemiller, 1991; Willis et al., 2005). }\end{array}$ \\
\hline 10. Relative width of mouth & $\mathrm{RWM}=\mathrm{MW} / \mathrm{MBW}$ & $\begin{array}{l}\text { Larger relative values of mouth length suggest fishes which feed of larger prey (Gatz Jr., } \\
\text { 1979; Balon et al., 1986; Winemiller, 1991; Ward-Campbell et al., 2005). }\end{array}$ \\
\hline 11. Protrusion index & $\mathrm{PI}=\mathrm{LSO} / \mathrm{LSC}$ & $\begin{array}{l}\text { This index had high values for fishes which feed upon smaller prey, that is, fish that protract } \\
\text { more the mandible and maxillae. Those that protract less, or fail to protract, bite and are } \\
\text { able to feed upon larger prey (Allev, 1969; Gatz Jr., 1979; Winemiller, 1991; Willis et al., } \\
\text { 2005). }\end{array}$ \\
\hline 12. Eye position & $\mathrm{EP}=\mathrm{EH} / \mathrm{HdH}$ & $\begin{array}{l}\text { This index is related to foods detection and it provides information on the visual predation } \\
\text { activities (Pouilly et al., 2003). It can indicate the preferential position of the species in the } \\
\text { water column. }\end{array}$ \\
\hline 13. Relative area of eye & $\mathrm{RAE}=\mathrm{EA} /(\mathrm{SL})^{2}$ & $\begin{array}{l}\text { This index is related to food detection and it provides information on the use of vision in } \\
\text { predation activities (Pankhurst, 1989; Pouilly et al., 2003). }\end{array}$ \\
\hline 14. Relative area of dorsal fin & $\mathrm{RAD}=\mathrm{DA} /(\mathrm{SL})^{2}$ & $\begin{array}{l}\text { Dorsal fins with larger relative areas have better capacity of stabilization in deflections } \\
\text { (Gosline, 1971). }\end{array}$ \\
\hline 15. Relative area of caudal fin & $\mathrm{RAC}=\mathrm{CA} /(\mathrm{SL})^{2}$ & Caudal fins with larger relative areas are important for the acceleration (Balon et al., 1986). \\
\hline 16. Aspect ratio of caudal fin & $\mathrm{ARC}=(\mathrm{CH})^{2} / \mathrm{CA}$ & $\begin{array}{l}\text { Fishes showing higher aspect ratio of the caudal fin are active and continuous swimmers. } \\
\text { These fish have a tendency for greater caudal fin bifurcation and reduction of area (Keast \& } \\
\text { Webb, 1966; Gatz Jr., 1979; Balon et al., 1986). }\end{array}$ \\
\hline 17. Relative area of anal fin & $\mathrm{RAA}=\mathrm{AA} /(\mathrm{SL})^{2}$ & $\begin{array}{l}\text { Larger relative area indicates higher maneuverability capacity and movement stabilization } \\
\text { (Breda, 2005). }\end{array}$ \\
\hline 18. Aspect ratio of anal fin & $\mathrm{ARA}=(\mathrm{AL})^{2} / \mathrm{AA}$ & $\begin{array}{l}\text { Anal fins with larger aspect ratio indicate a higher capacity to make rapid progression and } \\
\text { regression movements (Breda, 2005). }\end{array}$ \\
\hline 19. Relative area pectoral fin & $\mathrm{RAPt}=\mathrm{PtA} /(\mathrm{SL})^{2}$ & $\begin{array}{l}\text { The pectoral fin area is generally high for slow swimming species, which use the pectoral } \\
\text { fin for maneuverability, as some characids. Moreover, pectoral fin area also can be high for } \\
\text { fishes that exploit habitats with intense current, as the siluriforms (Watson \& Balon, 1984; } \\
\text { Wilga \& Lauder, 1999). }\end{array}$ \\
\hline 20. Aspect ratio of pectoral fin & $\mathrm{ARPt}=(\mathrm{PtL})^{2} / \mathrm{PtA}$ & $\begin{array}{l}\text { Higher ratio indicates long and narrow pectoral fins, which is more expected on fish that are } \\
\text { continuous high-speed swimmers and prefer pelagic regions (Wainwright et al., 2002). }\end{array}$ \\
\hline 21. Relative area of pelvic fin & $\mathrm{RAPv}=\mathrm{PvA} /(\mathrm{SL})^{2}$ & Pelvic fin area is relativity larger in benthic fish and smaller in pelagics fish (Breda, 2005). \\
\hline 22. Aspect ratio of pelvic fin & $\mathrm{ARPv}=(\mathrm{PvL})^{2} / \mathrm{PvA}$ & $\begin{array}{l}\text { Larger values for the aspect ratio of pelvic fin are found for pelagics fish and indicate a } \\
\text { higher capacity to balance. Lower ratio are associated to benthic fishes, because help to } \\
\text { maintain the body on the rocky bottoms of lotic habitats (Gatz, 1979). }\end{array}$ \\
\hline
\end{tabular}

